\title{
Cannon de Hermeto Pascoal: aspectos musicais e religiosos em uma obra-prima para flauta
}

\author{
Fausto Borém (UFMG, Belo Horizonte, MG, Belo Horizonte) \\ fborem@ufmg.br \\ Maurício Freire Garcia (UFMG, Belo Horizonte, MG, Belo Horizonte) \\ mgarcia@ufmg.br
}

\begin{abstract}
Resumo: Estudo de caso sobre Cannon de Hermeto Pascoal, obra para flauta, humming na flauta e sons pré-gravados, planejada como uma sessão espírita musical e gravada pelo compositor no disco Slaves Mass (PASCOAL, 1977). A partir do desenho artístico de uma pauta espiralada na capa interna do mesmo LP (PASCOAL e PEREIRA, 1977) e de uma transcrição baseada na faixa gravada, a partitura da obra foi detalhadamente reconstituída e editada (PASCOAL e BORÉM, 2010; incluida neste volume de Per Musi às p.80-82). A combinação das análises formal, escalar e proporcional da partitura e seu cruzamento com a análise espectral da gravação revelam grande unidade e uma íntima relação entre os conteúdos musicais e extra-musicais da obra, na qual elementos opostos dialogam: a improvisação e as camadas de superposição de sons pré-gravados, a sonoridade acústica e os sons manipulados, a performance individual e a coletiva, a estabilidade e a instabilidade modal, as linguagens popular (embolada, jazz modal, free jazz) e erudita (música concreta, atonalismo, cadenza, recitativo), os mundos terreno e espiritual. Apresenta também, em primeira mão, a abordagem analítica do "continuum separação-fusão paradoxal" da obra, a partir de ferramenta etnomusicológica criada e realizada por COSTA-LIMA NETO (2009). Inclui uma contextualização do papel da religião na música do "mago" multi-instrumentista, arranjador e compositor da música popular brasileira.
\end{abstract}

Palavras-chave: Hermeto Pascoal; música popular brasileira; modalismo; atonalismo; espiritismo e música; música eletro-acústica, análise musical.

\section{Cannon by Hermeto Pascoal: musical and religious aspects in a flute masterpiece}

Abstract: Case study on Cannon by Brazilian composer, arranger and multi-instrumentalist Hermeto Pascoal, a work for flute, flute humming and pre-recorded sounds, designed as a musical spiritism session and included in the LP Slaves Mass (PASCOAL, 1977). Departing from an artistic drawing of a music staff spiral included in the internal covers of the same LP (PASCOAL e PEREIRA, 1977) and a transcription based on the listening of the track in the same disc, the score of the work was reconstituted and edited in detail (PASCOAL e BORÉM, 2010; included in this issue of Per Musi, p.80-82). The combination of formal, scalar, proportional analyses with the spectral analysis reveal an intimate relation between the musical and extra-musical contents of the work, in which opposing elements dialog: improvisation and the layers of prerecorded sounds, acoustical sounds and manipulated sonorities, individual and the collective performances, stable and unstable modalities, the popular (the Brazilian embolada, modal jazz, free jazz) and the classical (musique concrète, bimodalism, atonalism, cadenza, recitative) languages, the earth and the spiritual worlds. It presents an original analytical approach of the work based on the "paradoxal separation-fusion continuum", devised and realized by ethnomusicologist COSTA-LIMA NETO (2009). It also includes a context of the religion role in the music of the so-called "mago" (wizard) of the Brazilian popular music.

Keywords: Hermeto Pascoal; Brazilian popular music; modalism; atonalism; spiritism and music; electro-acoustical music, music analysis. 
"Minha religião é a música"l. Hermeto Pascoal (GONTIJO, 2000, p.2)

"Eu rezo com a música, com o instrumento". Hermeto Pascoal (RODRIGUES, 2003)

„..tão único e diferente dos outros. . sua coragem de experimentar com todo e qualquer tipo de música num nivel muito avançado".

Flora Purim sobre Hermeto Pascoal (PURIM, 1977)

\section{1 - Hermeto Pascoal e Cannon: contextos musical e religioso}

A relação entre música e espiritualidade na vida de Hermeto Pascoal é muito imbricada e transparece tanto na sua produção artística quanto na sua filosofia de vida. $\dot{E}$ comum encontrar, salpicando sua numerosíssima obra, ${ }^{1}$ reflexos das diversas experiências religiosas que tem vivido. É muito comum ele escolher temas musicais, títulos de música e, principalmente, criar atmosferas de rituais derivados do catolicismo, espiritismo, umbanda, meditação e ritos indígenas. Assim, Hermeto sintetiza, ao mesmo tempo, a vocação brasileira para o sincretismo religioso e musical. Um relato detalhado de suas experiências religiosas relacionadas à música pode ser encontrado no artigo Hermeto Pascoal: experiência de vida e a formação de sua linguagem harmônica, publicado no presente número de Per Musi (BORÉM e ARAÚJ0, 2010, p.22-43).

São comuns os depoimentos de músicos que abdicaram de seus estilos de vida, cidades de origem e trabalhos só para fazerem parte de seus grupos ou de seu convívio, especialmente na fase da Escola Jabour (BARBOSA, 2001; COSTA-LIMA NETO,1999; John KRICH, 1993; ZWARG, 2009a). Foi esta dedicação e respeito religiosos pela qualidade musical que tornaram lendários os ensaios diários na casa de Hermeto no Rio de Janeiro, "from 2 to 8 pm", segundo entrevista do músico Jovino a GILMAN (2009), o que é corroborado por COSTA-LIMA NETO (2008, p.2 e 8): ". . . ensaiavam diariamente, das 14:00hs às 20:00hs, durante doze anos consecutivos, de 1981 a 1993", sendo que esse tempo de ensaio que era acrescido ". . p pela prática diária matinal, quando os músicos ensaiavam os trechos mais dificeis de suas partes individuais ..."

A devoção e envolvimento de Hermeto com a música muitas vezes sugere um estado de transe. Em Pendotiba (Niterói), Hermeto e seu grupo prolongaram o show de inauguração de uma casa de jazz por mais de cinco horas (COSTA-LIMA NETO, 2008, p.9). No $1^{\circ}$ Festival Internacional de Jazz de São Paulo, em 1978, ao lado de nomes como John McLaughlin, Chick Correa e Stan Getz, o show de Hermeto ". . . começou às 23 horas e prolongou-se até às 4 horas da madrugada. .." (MILLARCH, 1979). Para Hermeto, esse transe parece fazer parte de um processo que não pode ser interrompido como um evento meramente artístico com hora marcada para acabar. No seu segundo concerto do festival Som da gente no Town Hall em Nova lorque, em 1989, revoltou-se contra esta limitação que tentaram lhe impor na duração do concerto $e_{\text {, }}$ após iniciar uma música, parou e saiu do palco alegando que o tempo dado a ele tinha se esgotado. Apesar dos pedidos do público, em pé, Hermeto não retornou com seu grupo (MILLARCH, 1989).

Na esteira do prestígio da bossa-nova nos Estados Unidos, aumentou muito o trânsito de músicos brasileiros decididos a desenvolver sua carreira musical no exterior na década de 1960, a exemplo do casal formado pela cantora Flora Purim e o percussionista Airto Moreira, que se mudaram para os EUA em 1967. Depois das dificuldades iniciais, ficaram animados com a receptividade de seu trabalho, especialmente após seu contato profissional com Miles Davis. Em 1969, convenceram Hermeto a se mudar temporariamente para Nova lorque, para gravar o disco chamado Hermeto (1971). Ao falar de sua empatia com Miles Davis, apresentado por Airto Moreira, Hermeto Pascoal revela um pouco do lado espiritual:

"o repórter [da Radio France disse] '. . . o Miles Davis esteve aqui dando uma entrevista pra mim e eu perguntei pra ele se, quando ele morresse, ele gostaria de ser músico? Ai ele falou que gostaria de ser um Músico que nem o Hermeto Pascoal'. . . eu disse pro cara também: 'Se eu morresse eu gostaria de ser um músico como ele' " (BARROSO, 2009).

Menos de uma década mais tarde, Hermeto voltou aos Estados Unidos para gravar Slaves Mass (1977), no qual ficou ainda mais claro sua predileção pelo lado místico da música, o que já é sugerido no próprio título do álbum, que faz uma alusão à cultura afro-brasileira: missa dos escravos. Na faixa que dá nome ao disco, observa-se uma ampla utilização ritualística da voz (choros, gritos, gargalhadas, declamações, vocalizes), cuja sonoridade parece nos ". . . remeter à personagem conhecida na Umbanda como Pomba-gira. . ." (COSTA-LIMA NETO, 2010b, p.48). Hermeto consolida a atmosfera mística do disco com a utilização não convencional da voz em seis das sete faixas (COSTA-LIMA NETO, 2010b, p.48), e também com um intenso experimentalismo instrumental (técnicas expandidas da flauta, superposição de sons pré-gravados) e sonoridades exóticas (porcos grunhindo). Concorrem também para esta aura místico-religiosa as fotos na capa (Ex.1) - uma foto de Tom Copi cuja luz, em forma de aura, destaca os longos cabelos brancos de Hermeto que mostra, no lugar dos olhos, teclados refletidos em seus óculos - e na contra-capa do LP - uma foto avermelhada de Joel Sussman com Hermeto segurando um dos dois porquinhos texanos utilizados na gravação da faixa-título Slaves mass (veja BORÉM e ARAÚJ0, 2010, p.22-43, nesse volume de PerMusi).

Deste disco, escolhemos a faixa Cannon, composta por Hermeto em homenagem ao jazzista Julian "Cannonball" Adderley (1928-1976) ${ }^{2}$, um dos pioneiros do hard-bop (POLITOSKE, p.575), que atuou com Miles Davis até 1958 e se destacou também no free jazz na década de 1960 (KERNFELD, 1988, v.1, p.5-6), estilo da música popular 

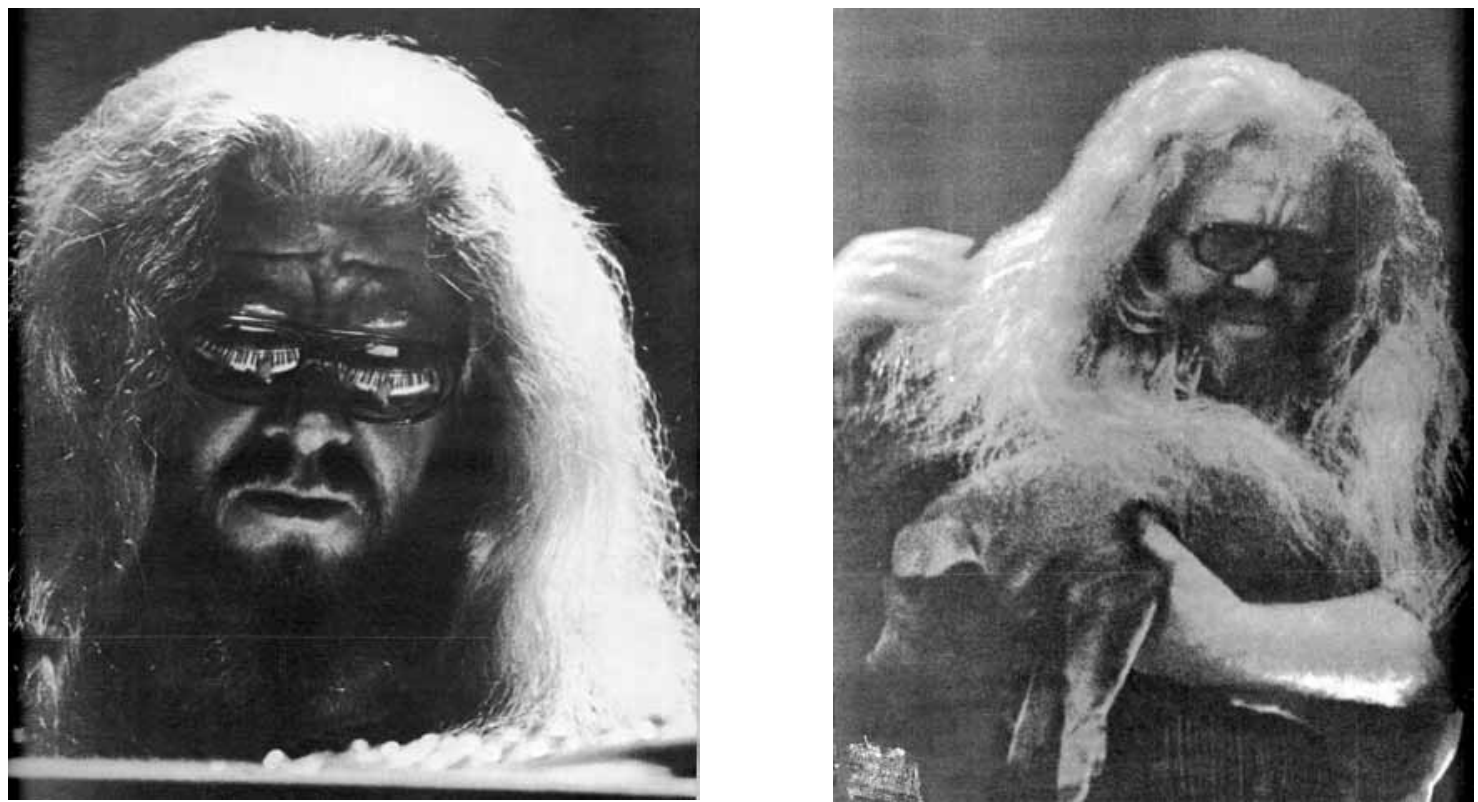

Ex.1 - Misticismo nas fotografias da capa e contra-capa do disco Slaves mass (1977) de Hermeto Pascoal (Fotos de Tom Copi e Joel Sussman).

esteticamente afim à música erudita aleatória. A análise de Cannon demonstra como, em Hermeto Pascoal, os aspectos musicais estão intrinsecamente ligados à sua visão mística e religiosa do mundo; neste caso, segundo a visão do espiritismo. Esta peça é centrada na performance de Hermeto na flauta transversal solo, ${ }^{3}$ à qual foram mixadas diversas camadas de som gravadas e manipuladas previamente (o que nos remete ao campo erudito da música concreta), como falas em português e em inglês, vocalizações diversas (gritos, risos, canto) e percussão.

Cannon ilustra a formação eclética de Hermeto, com referenciais tanto populares quanto eruditos, apesar de nunca ter frequentado escola de música alguma. Seu início pode lembrar tanto a liberdade harmônica e intervalar da música erudita expressionista ou pós-1950, quanto 0 experimentalismo do free jazz (veja Exs.5 e 6 à frente). No primeiro trecho rítmico e alegre da música, a cantora Flora Purim reage saudosa e instintivamente, no meio da gravação, com um "Eh, Brasil!" (c.39, veja Ex.9 à frente). Mas a métrica ternária deste trecho permite também outra leitura, pois poderia ter origem na experiência do compositor com vidas passadas, vidas de formação mais tradicional, erudita. Como se trata de uma "sessão espírita musical", podemos especular sobre a métrica ternária de Cannon e as influências que o próprio Hermeto diz ter recebido do outro mundo. É ele mesmo quem diz que ". . . acredita ter aprendido a tocar 'em 3/4'. ..", talvez como fruto do que COSTA-LIMA NETO (2010a) considera ser ". . . recordações que o alagoano supõe ter sido de sua outra 'encarnação' em Viena, importante centro cultural da música erudita européia. ..."

Ainda do ponto de vista do timing de distribuição dos eventos ao longo de Cannon, observa-se uma ocorrência notável próxima a 2/3 de duração da peça, ou seja, numa proporção equivalente à seção áurea. A linha melódica principal (flauta + humming; Observação: hummings são vocalizações no bocal da flauta) e o "coração batendo", antes assíncronos entre si, entram em fase (tornam-se sincronizados) momentaneamente (c.87-90; [03:4703:52], veja Ex.5 e mais detalhes na próxima seção deste artigo), para depois seguirem cada um seu próprio caminho, fora de fase, assíncronos. Do ponto de vista religioso, poderíamos associar este evento ao momento em que de fato se estabelece o contato entre o médium e o espírito desencarnado. Do ponto de vista musical, para resistirmos à tentação de associar este procedimento à prática histórica de polimetria de Charles Ives no começo do século XX (e cair no erro da decantada ideia de que procedimentos musicais "cultos" ou "sofisticados" sempre vieram do estrangeiro), basta lembrarmos das experiências da infância de Hermeto na praça de Lagoa da Canoa ouvindo dois, três, quatro eventos superpostos e independentes ao mesmo tempo (CAMPOS, 2006, p.134). Para Hermeto, a aprendizagem de seu caminho pelo mundo, sua cultura e religião acontece no encontro com o povo, em casa, nas ruas, nos bares, nos teatros, pelo mundo.

Finalmente, Cannon pode ser considerada uma obraprima do repertório da flauta por diversas razões. Primeiro, parece tratar-se da primeira peça surgida no cenário da música brasileira, até onde sabemos, para flauta e fita magnética. Segundo, trata-se de uma obra em que se vislumbra uma escrita altamente idiomática da flauta, não só com a sua utilização instrumental tradicional virtuosística dentro da linguagem modal expandida e dentro do espirito da cadenza de concerto, mas também por explorar eficientemente, um grande leque de formas de ataque e técnicas expandidas, 
como multifônicos e, especialmente, o humming. Outro aspecto que torna Cannon revolucionária e que também transgride a barreira entre os mundos erudito e popular, é a hibridação de práticas de performance que fazem referência a gêneros populares (como o jazz, a embolada ou o repente) e às práticas eruditas (como o modalismo quase-atonal, a música eletro-acústica, a cadenza de concerto), deixando irreconhecíveis os limites entre a composição prévia e a improvisação. Finalmente, em Cannon, todos os recursos composicionais, instrumentais e de técnicas de gravação em estúdio são utilizados de maneira integrada, funcional e criando grande unidade musical. Nessa obra, Hermeto Pascoal atingiu a expressão de um ritual religioso-musical que reflete não apenas a importância da experiência mística na sua vida, mas também a função social da música de uma maneira mais ampla, que aproxima diferentes povos, culturas e maneiras de tocar.

\section{2 - Análise dos dados eletro-acústicos da gravação de Cannon}

Texturalmente, Cannon foi construída com base em um solo de flauta ininterrupto sempre em primeiro plano, ao qual gradualmente se sobrepõe sons pré-gravados (vozes e percussão) produzidos por seis pessoas - músicos ou pessoas envolvidas no projeto de Slaves mass presentes no estúdio Paramount em Los Angeles: Hermeto Pascoal, Airto Moreira, Flora Purim, Hugo Fattoruso, Raul de Souza e Laudir de Oliveira. As vozes aparecem em dois planos distintos: falas em primeiro plano, sem manipulação e falas e sons vocais em segundo plano, com manipulação da velocidade de reprodução. Hermeto, sempre liderando o grupo, declama fragmentos em português em [00:38], [00:52], [01:46], [02:17], [03:40], [04:10], [04:18], [04:35] e [04:37]). Esses fragmentos, quase sempre são seguidos de livres e esporádicas traduções para o inglês por outra voz masculina, possivelmente a de Airto Moreira (pode-se observar que é um brasileiro quem fala pela escorregadela na gramática da língua inglesa "everybody can express [sic] myself" em [02:12]). As falas femininas são de Flora Purim, notadamente uma em inglês e outra em português. Airto Moreira, junto com Flora Purim, foi quem ciceronou e parece ter sido o porta-voz de Hermeto na sua estadia nos Estados Unidos (Hermeto aparentemente falava pouco inglês na época).

Repetidas e atentas audições de Cannon permitiram a anotação dos seguintes trechos de fala sem manipulação de alturas, ainda assim sujeita a erros, pois nem sempre são audíveis e há uma grande superposição de sons manipulados e não manipulados, além de mudanças de canal e seu efeito de espacialização:

\footnotetext{
- em [00:03]: (Voz masculina) "quem falou?";

- em [00:38]: (Hermeto) "o que você fez aqui ... todos os lugares"

- em [00:45]: (Voz masculina [Airto Moreira?]) "forever"

- em [00:52]: (Hermeto) "o que você fez aqui, continua fazendo muito mais"

- em [01:00]: (Voz masculina) "forever"

- em [01:19]: (Voz masculina) "I think I'm going to see you...I am sure I'll see you"
}

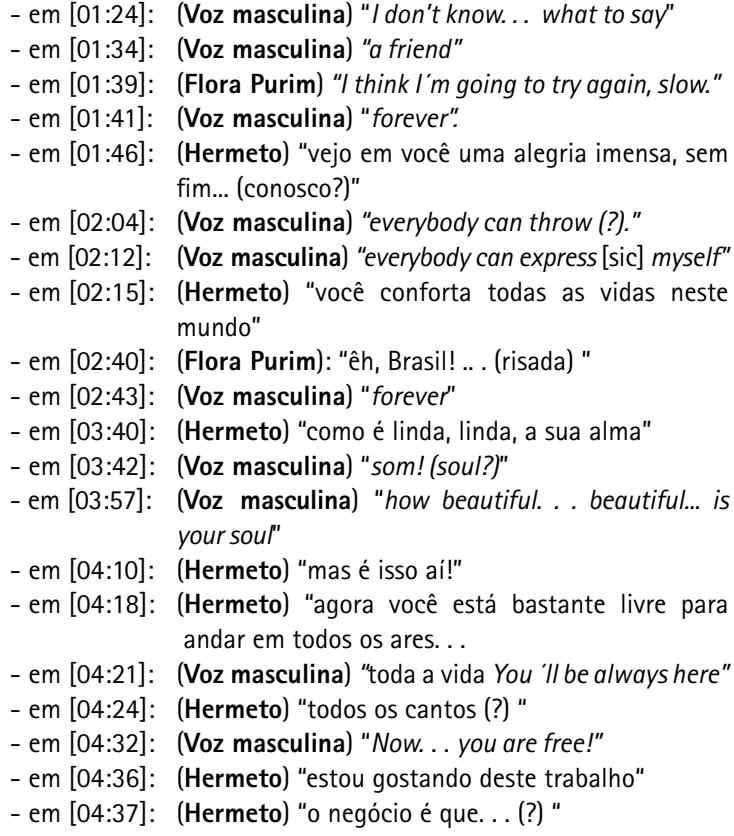

Em segundo plano, e utilizando o recurso de aumento de velocidade de reprodução da fita magnética (o que resulta na transposição de uma oitava ou mais acima das alturas originais; trechos que, daqui para frente, serão chamados simplificadamente de "oitavados"), surgem vozes faladas, gritadas ou cantadas (Flora Purim faz vocalizes modais em [01:48], [01:56], [02:02], [02:12], [04:20] e [04:48]). Surgem também fragmentos percussivos, como sons sibilados com a boca em [02:08]; palmas em [03:14] e [03:24], percussão esparsa em metal entre [04:05] e [04:36], percussão mais rítmica em [04:42] e como um "rulo" em [04:47] e [04:49]. Essas vozes e percussões "oitavadas", estrategicamente distribuídas ao longo da forma musical, criam uma atmosfera não-terrena crescente e apropriada para a sugestão de um ritual místico: lembram vozes do além, sons de aves, de crianças, risadas, gritos, vocalizes agudíssimos, glissandi etc. Devemos ter em mente que, na época da gravação do disco (final da década de 1970), os recursos tecnológicos de manipulação sonora ainda estavam mais próximos da herança da final da década de 1940, deixada pelos pais da música concreta - os franceses Pierre Schaeffer e Pierre Henri (EMMERSON e SMALLEY, 2001, p.60) - e ainda distantes do advento, em 1983, do protocolo MIDI no processamento de eventos e sinais sonoros (EMMERSON e SMALLEY, 2001, p.61) e das facilidades de manipulação sonora dos modernos softwares (como a técnica de alterar o andamento sem alterar as alturas, por exemplo). Assim, para muitos dos ouvidos de hoje, a porção eletro-acústica de Cannon pode soar "datada", e lembrar antigas trilhas de filmes ou seriados de TV que, psico-acusticamente, relacionamos com seres alienígenas (ou, no contexto da obra, espíritos desencarnados).

Para tentar reconhecer o conteúdo das falas e outros sons "oitavados", reduzimos a velocidade de reprodução em $25 \%$ e $50 \%$, o que permitiu notar que a maioria dos efeitos foi, de fato, feita com o aumento de $100 \%$ da velocidade do sinal original, um recurso de realização 
bastante simples e muito utilizado por compositores de música concreta desde a década de 1950.

Abaixo, segue uma listagem de trechos de sons (falas e percussão) manipulados e superpostos que puderam ser compreendidos por meio da redução da velocidade de reprodução de Cannon:

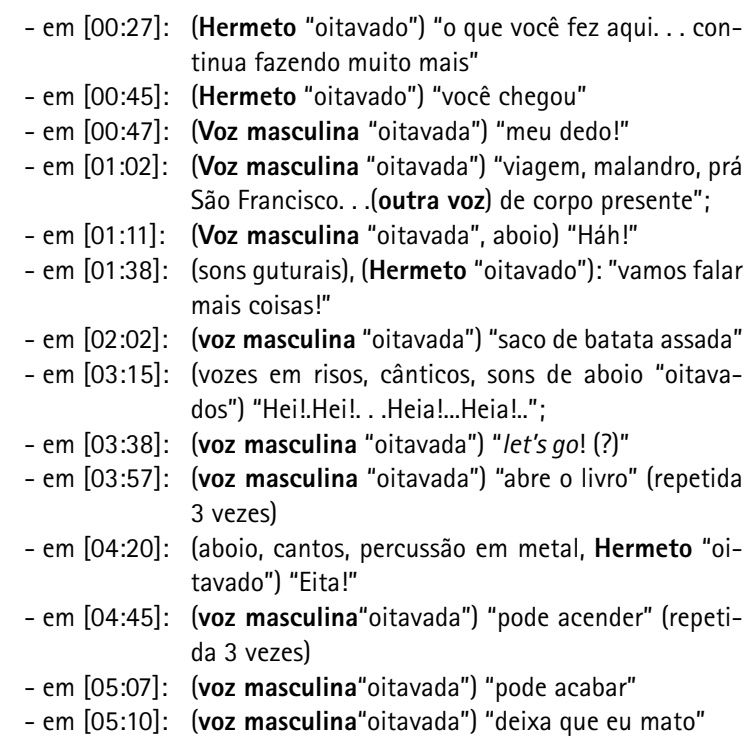

Percebe-se claramente que algumas das falas não têm relação direta com o tema da sessão espírita de Cannon. São frases comuns do dia-a-dia dos estúdios, como possíveis falas sobre a necessidade de silêncio e concentração no início dos takes de gravação ("quem falou?" [00:03]), um teste de microfone ("som!" em [03:42]), a satisfação musical na gravação (Hermeto: "estou gostando deste trabalho" em [04:36]), um comentário sobre detalhes da gravação (Hermeto: "mas é isso aí!" em [04:10] "o negócio é que. .. " em [04:37]), possível referência ao hábito dos músicos de comerem ou fumarem dentro do próprio estúdio ("saco de batata assada" [02:02] ou "deixa que eu mato" em [05:10]), a necessidade de deslocamento entre cidades da Califórnia ("viagem, malandro, a São Francisco...de corpo presente" em [01:45]; observamos que o disco estava sendo gravado na cidade de Los Angeles; note que, ao dizer "corpo presente", um dos presentes utiliza um vocabulário religioso). Essa habilidade de Hermeto de transformar qualquer som em música é característica desde a sua infância (BORÉM e ARAÚJ0, 2010, p.22-42, nesse volume de Per Musi) e reflete a ". . . coragem de experimentar com todo e qualquer tipo de música. .." de que fala Flora PURIM (1977).

Mas Hermeto utiliza, na maior parte de Cannon, os sons da fala (e também vocalizes e percussão) manipulados, que parecem guardar uma relação direta com o assunto da música, seja dando orientações de performance para o grupo ("vamos falar mais coisas" em [01:38]), seja em detalhes do possivel ritual ("abre o livro", repetido três vezes em [04:57] e "pode ascender", repetido três vezes em [04:45]).

Esta relação texto-música fica mais evidente na utilização de sons não manipulados, na voz Hermeto Pascoal, em português, que lidera o grupo: "o que você fez até aqui. .. todos os lugares" em [00:38], "o que você fez aqui, continua fazendo muito mais" em [00:52], "vejo em você uma alegria imensa, sem fim" em [01:46], "você conforta todas as vidas deste mundo" em [02:17], "como é linda, linda, a sua alma" em [03:40], "agora você está bastante livre para andar por todos os lugares. . . pelos rios(?)" em [04:18], "estou gostando deste trabalho" em [04:35]. Ou, então, nas interações quase imediatas e fragmentadas em inglês, na voz de Flora Purim: "I think I'm going to try again... slow" ("acho que vou tentar de novo... devagar") em [01:39]. Mas, principalmente (e possivelmente) na voz de Airto Moreira: "forever" (para sempre) em [01:00], "I think I'm going to see you. . .l am sure I'll see you" ("acho que vou ver você. . .tenho certeza que vou ver você") em [01:19], "I don't know. . . what to say. .. to you" ("não sei o que dizer a você") em [01:24], "a friend" ("um amigo") em [01:34], "forever" (para sempre) em [02:43], "everybody can express [sic] myself" ("todo mundo pode se expressar") em [02:12], "how beautiful. . beautiful... is your soul!" ("que linda, linda é a sua alma!") em [03:57], "toda a vida You 'll be always here" (toda a vida você estará sempre aqui) em [04:21], "Now. . you are free!" ("agora você está livre!") em [04:32].

A repetição de frases completas ("o que você fez aqui" aparece três vezes, sendo uma vez "oitavada") e recorrência de algumas palavras ("alegria", "alma", "vida", "friend", "forever", "free" etc.) contribui não apenas para criar a atmosfera mística, mas também para, composicionalmente, dar unidade à obra. Tanto a flauta quanto os sons pré-gravados acontecem, boa parte do tempo, de forma declamatória. Embora o clima seja de improvisação (Flora afirmou que foi assim, como vimos acima), Hermeto exerce um grande controle sobre os materiais temáticos (harmônicos, melódicos, rítmicos, de articulação e tímbricos) que utiliza, como veremos mais à frente. Por isso, a repetição de materiais temáticos tanto na flauta quanto no emprego dos sons pré-gravados parece remeter a uma complexa e estruturada improvisação motívica.

Além das vozes, Hermeto utiliza a manipulação de outros sons pré-gravados, adicionados ao canal principal da flauta, como elemento unificador de Cannon. As "batidas de coração", por exemplo, que seriam um dos sinais da vida depois da morte de Cannonbal e uma prova de sua comunicação com Hermeto e seus músicos, recorrem cinco vezes (veja Ex.5 à frente), pontuando todas as seções da forma musical (a forma $A$ (ba) B $A^{\prime}$ Codetta é explicada mais à frente no Ex.5 e no texto que o precede):

Seção A: nos c.7-15; em [00:35-01:15]; dur.40' Ponte ba: nos c.45-55; em [02:47-03:07]; dur.22' (continua na Seção B)

Seção B: nos c.56-68 (continuação da Ponte ba); em [03:07-03:29]; dur.22' e nos c.83-124; em [03:4304:26]; dur.43'

Seção $A^{\prime}:$ no c.140; em [04:45:-04:46]; dur.1' (uma batida só!) 
Codetta: nos c.143; em [05:00-05:13]; dur.13', as "batiads de coração" finalizam a música sozinhas

Outro elemento unificador em Cannon é a recorrência de materiais cromáticos (algumas vezes causando instabilidade modal) em pontos de articulação importantes, no início ou final das seções da forma:

Seção A: o início (c.1-9) e finais (c.30-33) quase-atonais (veja Ex.6 e Ex.7, à frente);

Ponte ba: a escala cromática descendente completa, próximo ao final (c.51-55; veja Ex.9, à frente);

Seção $B$ : apojaturas cromáticas e terças cromáticas descendentes próximas ao final (c.117-124; veja Ex.10, à frente) e cromatismo Mi-Mib-Ré ao final (c.137-138);

Seção $A^{\prime}$ : modalismo instável em toda a seção (c.139142; veja Ex.11, à frente);

Codetta: bicorde de segunda menor Lá-Sib sustentado por 10 segundos (c.143; veja Ex.12, à frente).

Do ponto de vista instrumental, Hermeto toca a flauta em uma posição mais diagonal em relação ao corpo (menos horizontal; mais confortável, segundo ele) com uma embocadura relaxada (que resulta em sonoridades com mais ar, conhecidas com soffio ou sons eólios) e quase sempre sem vibrato, seguindo uma tradição que se consolidou na música popular brasileira a partir do modelo do canto liso e declamado deixado por Mário Reis (GIRON, 2001, p.240) na década de 1930 e reafirmado por João Gilberto na década de 1960 (GIRON, 2001, p.17). Hermeto prefere utilizar outros efeitos expressivos (como diversos tipos de glissando, crescendi súbitos), contrastes de articulação (como o staccato e o marcato), timbres (como a aproximação da fala humana) e técnicas expandidas (como multifônicos e diversos tipos de humming).

Uma importante referência que Hermeto Pascoal pode ter encontrado na sua viagem aos EUA, ou antes dela, por meio de gravações, é a música revolucionária do multiinstrumentista cego de jazz norte-americano Rahssan Roland Kirk (1935-1977), na qual explorou técnicas instrumentais expandidas e técnicas de estúdio como uma ferramenta composicional. Na flauta transversal (que também tocava assoprando pelo nariz) se destacou como um pioneiro do humming, se tornando o modelo para importantes seguidores como Jeremy Steig, Thijs van Leer e lan Anderson da banda Jethro Tull (RAHSSAN, 2010). Rahssan também tinha um lado místico, como ilustra o nome de seu disco I talk with the spirits (Limelight; Nola's Penthouse Sound, 1964). Na faixa de mesmo título, assim como Hermeto em Cannon, RAHSSAN (1964) começa com uma quinta justa ascendente (Mi-Si), sem vibrato, e utiliza a linguagem modal (pentatônica em Sol). Assim como Hermeto em Cannon, Rahssan também utiliza o humming extensivamente, embora quase sempre com a voz dobrando as mesmas notas da flauta. Fechando o conjunto de similaridades e coincidências, Rahssan tam- bém se destacou no hard bop e free jazz, foi pioneiro das práticas de música concreta na música popular, colaborou com Cannonball Adderley e veio a falecer no ano de lançamento do disco de Hermeto.

A sonoridade e técnica característica de Hermeto Pascoal na flauta pode ser apreciada no espectrograma mostrado no Ex.2: (1) uma composição de parciais muito regular, em que pode ser observada uma frequencia fundamental mais forte que os harmônicos superiores, (2) uma sonoridade non vibrato, caracterizada pela ausência de oscilação detectável de frequencia ou intensidade no espectrograma) e (3) uma "nuvem" de frequências agudas, que indicam ruídos de ar característicos do som de flauta de Hermeto Pascoal. Ainda no Ex.2, pode-se observar, no solo de flauta sem acompanhamento, a maneira particular com que ele termina algumas notas abruptamente (como a $1^{\text {a }}$ nota - em anacruse, a $3^{\text {a }}$ e a $6^{a}$ notas, logo no início da peça).

Em relação às técnicas instrumentais expandidas da flauta, Hermeto utiliza glissandi (c.6, 10-11, 13-14, 16,22-26, $28,34,58,69-72,140-142$ ) e multifônicos de oitava (c.5, 18, 79 e 89) e de terça maior (c.29), esporadicamente inseridos na linha melódica. Utiliza também a técnica do humming extensivamente, desde o c.31 (em [02:15], próximo ao final da Seção $A$ ) até o final da obra, ou seja, durante exaustivos 2'58", o que é um dos grandes desafios na performance desta obra. Pierre Yves-Artaud, uma das mais destacadas autoridades da flauta contemporânea, descreve os quatro tipos de humming na flauta: (1) pedal na flauta com melodia na voz; (2) pedal na voz com melodia na flauta; (3) flauta e voz em uníssono ou em oitavas e (4) o mais difícil, flauta e voz com melodia independentes o qual ". . é extremamente complexo e requer um controle perfeito" (ARTAUD, 1995, p.119). Hermeto demonstra toda sua genialidade como compositor e intérprete realizando esses vários tipos de humming (dois dos quais são mostrados no espectrograma do Ex.3). E vai além, realizando o humming nasal e um longo humming em terças paralelas. Abaixo, seguem as ocorrências e tipos de humming de Hermeto Pascoal em Cannon:

\section{Seção A:}

- humming com a flauta em movimentos contrários (c.31-32);

- humming nasal sem o som da flauta (três primeiras notas do c.33);

- humming em uníssono com a flauta (c.33-35);

\section{Ponte ba:}

- humming em uníssono com a flauta (c.36-50);

- humming cromático descendente com pedal na flauta (c.51-55);

\section{Seção B:}

- humming em uníssono com a flauta (c.55-91);

- humming em terças paralelas com a flauta (c.91-94);

- humming em uníssono com a flauta (c.95-103); 


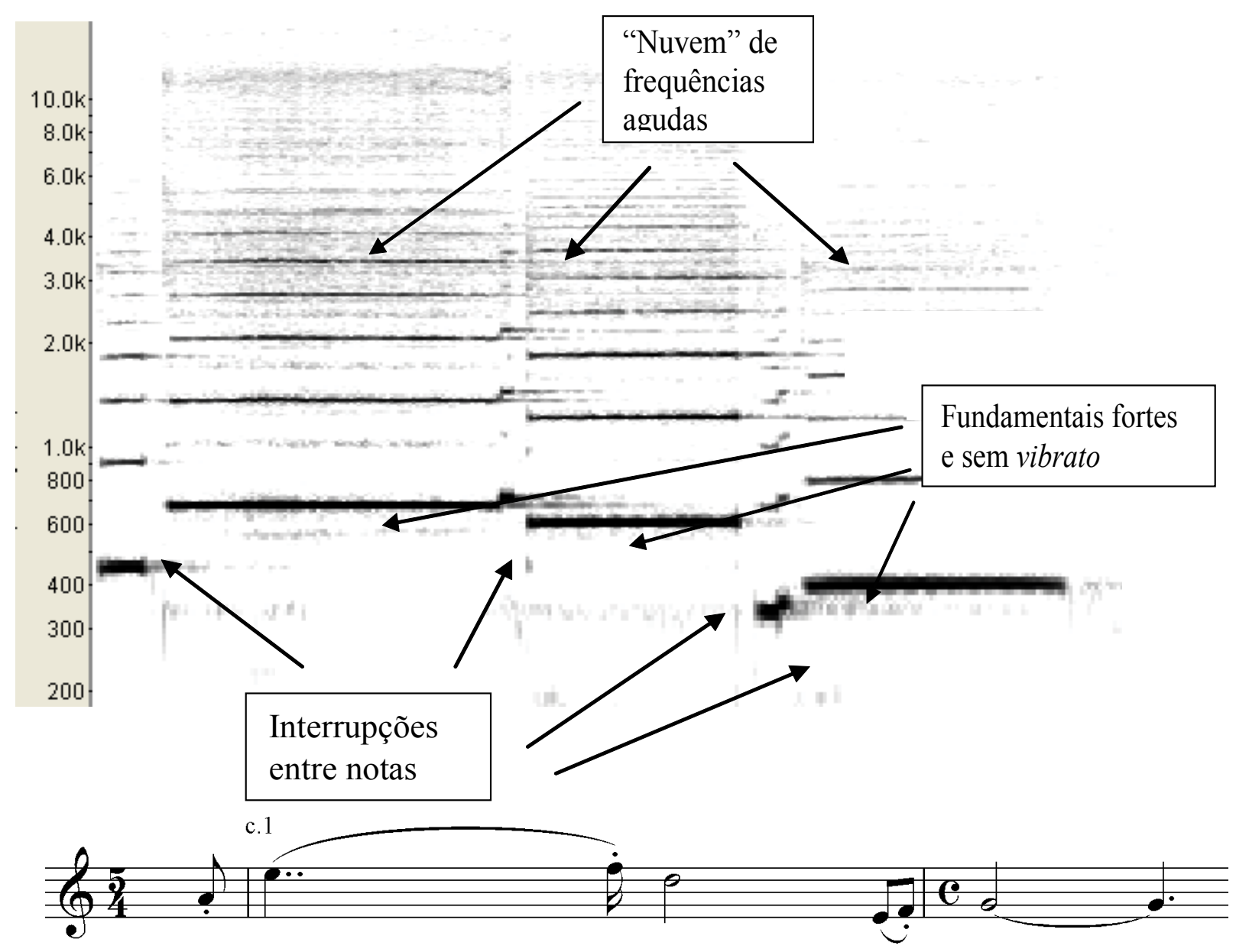

Ex.2- Espectrograma mostrando a sonoridade de Hermeto Pascoal na flauta no início de Cannon: composição de harmônicos muito regular, ausência de vibrato e "nuvem de frequências agudas (medidas no eixo vertical em $\mathrm{Hz}$ ).

- humming em terças paralelas com a flauta (c.104-116);

- humming em portato paralelo a com pedal da flauta (c.117-118)

- humming em terças paralelas com a flauta

(c. 119-124);

- humming em uníssono com a flauta (c.124-138);

\section{Seção $A^{\prime}$ :}

- humming em uníssono com a flauta (c.139-142);

\section{Codetta:}

- humming em unissono com a flauta e depois descendente com

a flauta em pedal (c.143).

\section{3 - Análise do contexto, partitura e perfor- mance de Cannon}

Para a parte interna da capa do LP Slaves Mass, o artista plástico Ruy Pereira criou um desenho artístico que inclui uma pauta em espiral com um coração no centro (Ex.4), na qual está notado parcialmente o solo de flauta de Hermeto Pascoal na música Cannon (PASCOAL e PE-
REIRA, 1977). No seu texto de apresentação desse disco, a cantora Flora Purim fala sobre a "transcrição" que Ruy Pereira realizou "nota por nota" (PURIM, 1977). A transcrição publicada em 1977 não é completa e, na verdade, apesar de desenhada por Ruy Pereira (que não tinha formação musical), foi feita pelo próprio Hermeto, segundo nos informou Jovino SANTOS NETO (2009).

Para comparar a versão da partitura publicada na capa interna do disco com a gravação, foi necessário "desenrolar" os 124 compassos do desenho da partitura espiralada. Depois, a partir da audição da gravação, foi possível verificar que faltavam 19 compassos na partitura do disco (os c.47-55, referentes a um trecho lento em que a voz faz

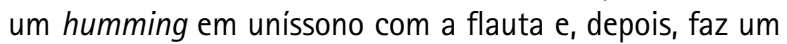
humming cromático descendente, enquanto a flauta segura um pedal em Sol), o que deixa Cannon com 143 compassos, de fato. Além disso, a gravação permite perceber que há muitas simplificações e discrepâncias na partitura original. Por exemplo, não foi anotada nenhuma das vozes (em uníssono, em movimento contrário ou em movimento contra um pedal sustentado) decorrentes da utilização 

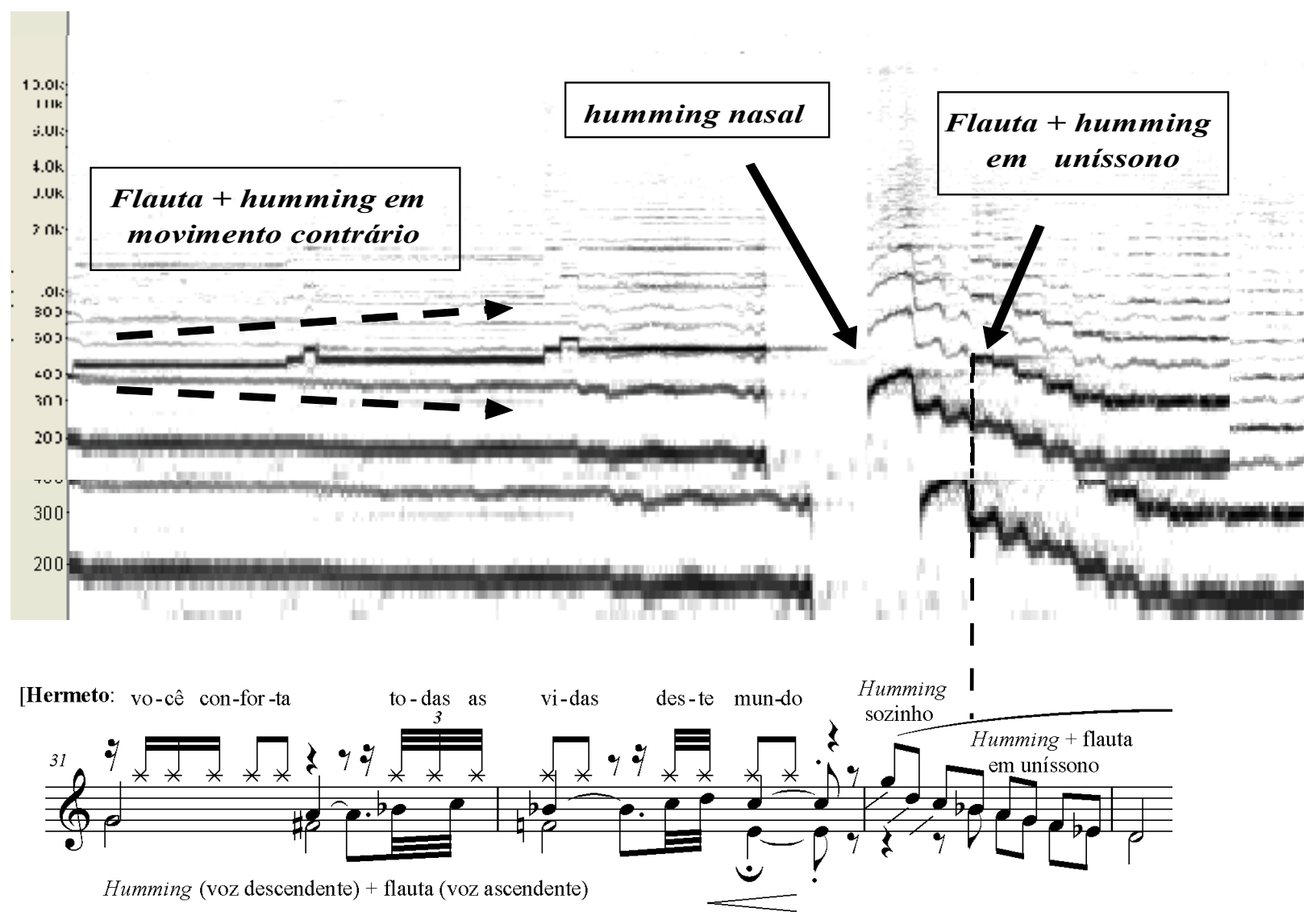

Ex.3 - Espectrograma com dois dos vários tipos de humming realizados por Hermeto Pascoal em Cannon: (1) humming e voz em movimentos contrários (c.31); (2) humming em "uníssono" (c.33; na verdade, em oitavas paralelas, devido à transposição da voz uma oitava abaixo).

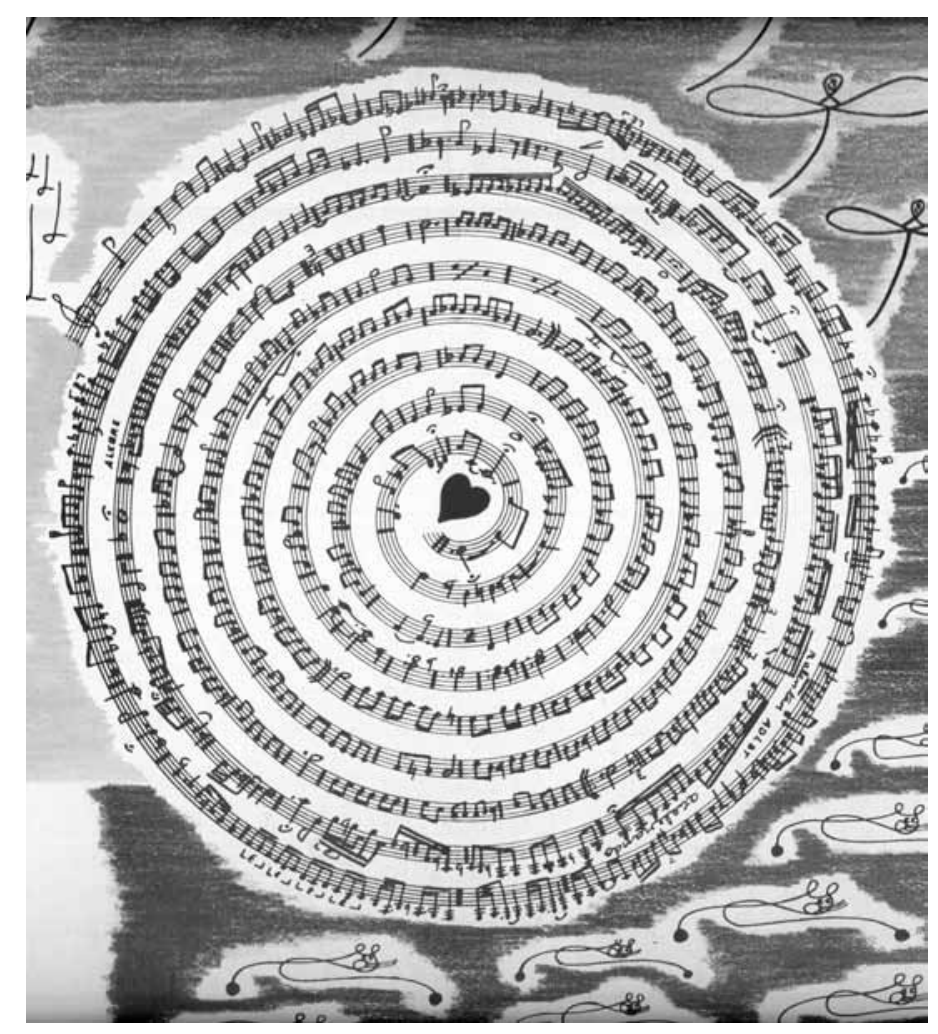

Ex.4 - Partitura espiralada de Cannon desenhada por Ruy Pereira a partir da transcrição de Hermeto Pascoal no LP Slaves Mass (PASCOAL e PEREIRA, 1977). 
de humming por Hermeto. Finalmente, há muitas notas, ritmos, métricas e sinais gráficos inconsistentes, equivocados ou dificeis de serem lidos. A partitura completa de Cannon, reconstruída em detalhe com base na gravação de Hermeto de 1977, está publicada no presente número de Per Musi, às p.80-82 (PASCOAL e BORÉM, 2010).

Flora Purim ainda acrescenta que a transcrição de Cannon ". . . levou seis horas. . ." porque foi uma experiência de total improvisação. A finalidade foi de se preparar uma sessão espiritual e tentar comunicação com Cannonball. Alguns de nós o fez [sic.] com muito sucesso" (PURIM, 1977). Comentando este episódio, o jornalista Aramis MILLARCH (1977), amigo de Airto Moreira, confirma que teria ocorrido

". . . 'uma verdadeira sessão de espiritismo realizada no estúdio' segundo o relato que o próprio [Airto] Guimorvan [Moreira] nos prestou na semana passada. Hermeto, Hugo Fattoruso, Raul de Barros [sic; Na verdade, trata-se do trombonista Raul de Souza, cujo nome de nascimento era João de Souza e foi mudado por sugestão de Ary Barroso], Laudir de Oliveira, Airto e Flora Purim - que participaram da faixa, sentiram algo de espiritual ocorrer, como se a alma de Julian 'Cannonball' Adderley (1928-1976), grande amigo de todos os músicos participantes da sessão e a quem a faixa era dedicada, tivesse 'baixado' sobre eles. .."
Uma análise formal de Cannon revela uma obra altamente estruturada e unificada. Embora a escrita um tanto rapsódica de Cannon possa sugerir uma sucessão de eventos desconectados, especialmente com a superposição de diversas camadas sonoras (com vozes soli declamadas em português e inglês; vozes faladas ou cantadas coletivas e manipuladas em segundo plano; percussões manipuladas em segundo plano) sobre o solo da flauta (e flauta com humming), sua forma pode ser descrita como uma forma canção $A$ (ponte ba) $B A^{\prime}$ Codetta, sendo que a ponte ba é construída com materiais temáticos contrastantes das Seções $\boldsymbol{B}$ e $\boldsymbol{A}$. Esta forma ternária em arco é apropriada para emular o caráter progressivo e em arco de uma sessão espírita - (1) o contato gradual e crescente, (2) o clímax, e (3) a despedida gradual e decrescente. As Seções $\boldsymbol{A}$ e $\boldsymbol{B}$ apresentam muitos contrastes entre si em relação ao andamento, métrica, articulações, materiais harmônicos e contorno melódico. Na gravação do disco Slaves mass, os 143 compassos de Cannon duram 5'13'. 0 Ex.5 apresenta uma esquema gráfico detalhado com as seções formais, seção áurea e os principais eventos da obra, com indicações de número de compasso e timings.

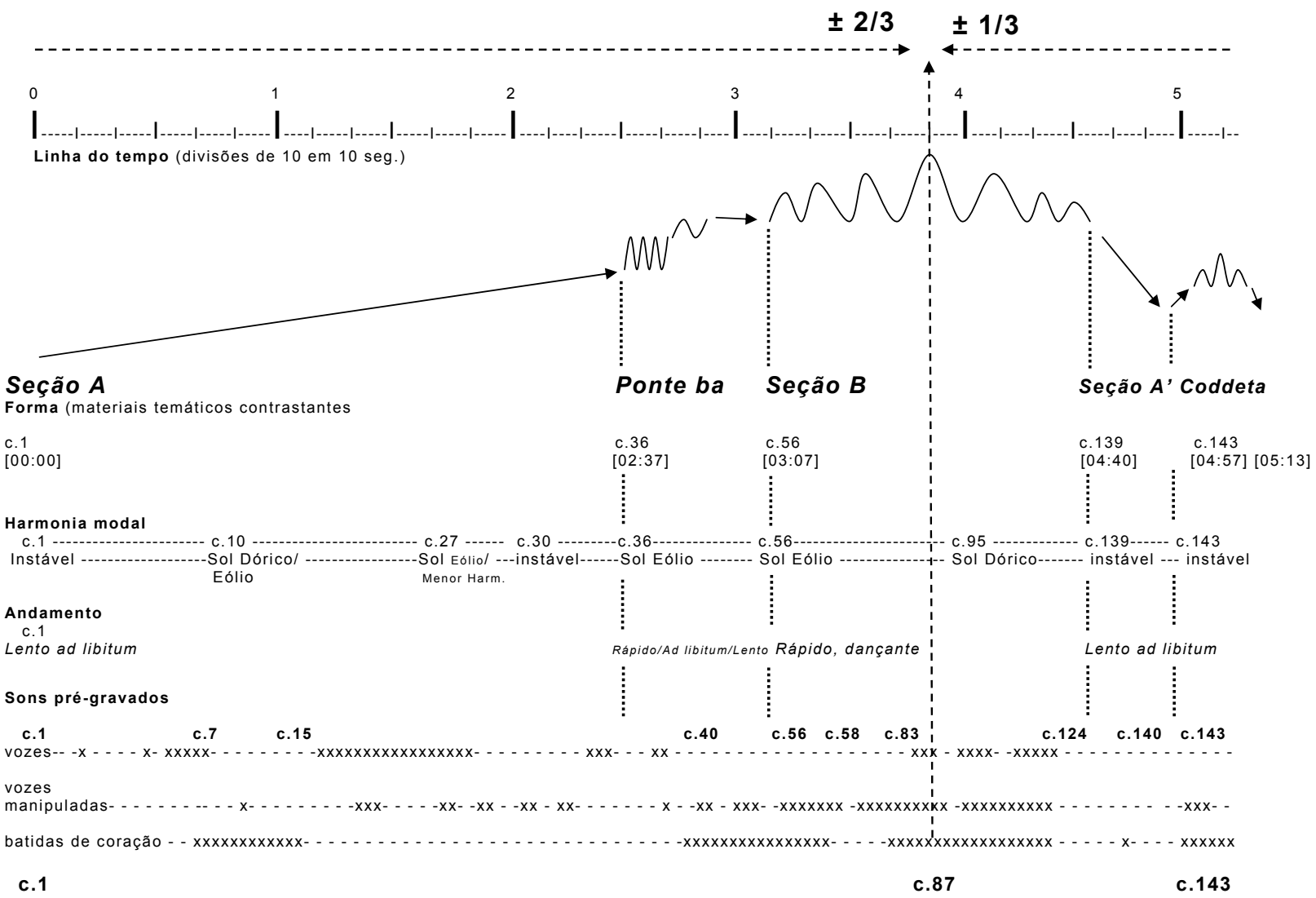

Ex.5 - Esquema gráfico analítico de Cannon de Hermeto Pascoal (seções formais, seção áurea e principais eventos com timing e número de compassos aproximados) 
A Seção $A$ (c.1-35; [00:00-02:37]; dur. 2'37'), dentro do programa do obra (uma sessão espírita musical), poderia ser chamada de "Preparação para o contato com o mundo espiritual". É em andamento Lento ad libitum, o que lhe confere um caráter de recitativo, com métrica quaternária na maior parte do tempo (há dois compassos 5/4 e um 3/4). Harmonicamente, é caracterizada por uma grande instabilidade modal inicial, em que os centros modais passageiros de Lá, Sol, Mib, Ré, Fá, Sib, Láb, Fá, Dó e Sol se sucedem em um curto espaço de tempo (c.1-12; Ex.6), gerando um ambiente quase-atonal. As frases, que sugerem um legato cantabile, exibem contornos melódicos com saltos e intervalos incomuns para a música popular.

Em seguida, no trecho central da Seção $\boldsymbol{A}$, observa-se maior estabilidade harmônica, embora não ocorra uma definição de um centro modal, mas sim uma polarização, que primeiro oscila entre Sol Dórico e Sol Eólio (c.10-26) e, depois, entre Sol Eólio e Sol menor harmônico (c.27-29). Digno de nota neste trecho é o crescendo finalizado com ataque brusco e respiração na nota Dó do c.44, criando um efeito que tanto pode lembrar as performances programáticas dos pífanos nordestinos, quanto as primeiras técnicas da música eletro-acústica (afinal, além do solo de flauta, tudo o mais em Cannon foi construído com técnicas de estúdio), como tocar a fita gravada de trás para frente em um decrescendo. A Seção A termina instável harmonicamente (Ex.7), mais ainda do que no início, devido à sucessão de quartas justas descendentes Láb-MIb, Si-Fá\#, Lá-Mi, Dó\#-Sol\#, que "resolvem" em dois tritonos: Sol\#-Ré e Fá\#-Dó (c.30). 0 trecho final da Seção $A$ (c.31-35; [02:15-02:37]) contém um dos momentos mais delicados de Cannon e pode ser descrito como uma "reza" intima de Hermeto Pascoal. Apenas ele participa, ainda que realizando três vozes diferentes (c.31-32): (1) uma declamação suave e sincronizada com (2) uma melodia ascendente na flauta e (3) um baixo cromático descendente em humming na flauta (veja Ex.3 acima).

Nos trechos modalmente mais instáveis da Seção $\boldsymbol{A}_{\mathbf{1}}$ a articulação é em legato cantabile com muitos saltos melódicos, com frases típicas da música erudita atonal. Nos trechos de polarização modal, a articulação também é em
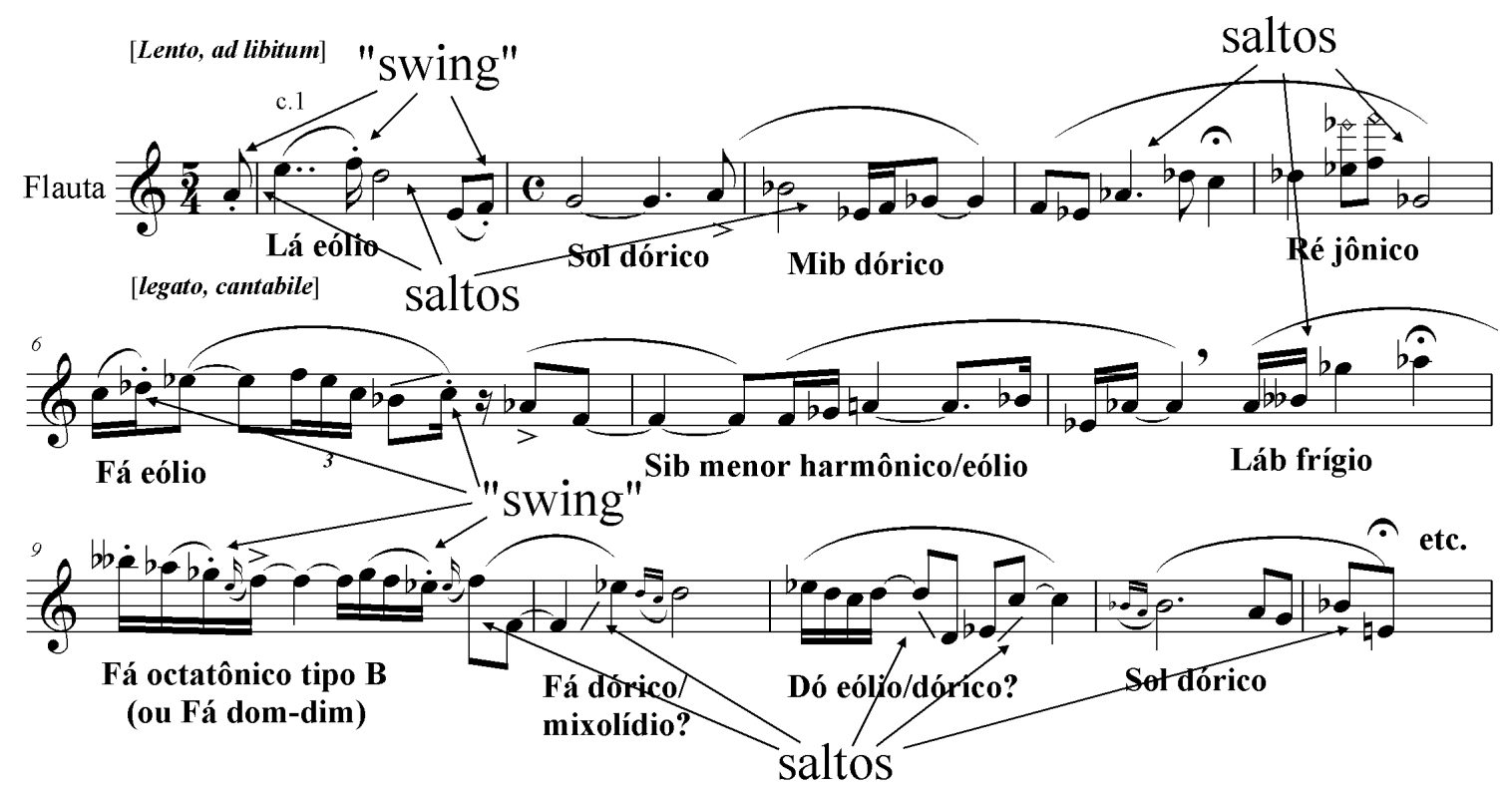

Ex.6 - Início da Seção A em Cannon de Hermeto Pascoal: contorno melódico com saltos e portamenti, articulação emulando swing e instabilidade modal. 
legato, mas há grande recorrência de graus conjuntos que se organizam em gestos virtuosísticos mais prováveis de serem encontrados em cadenzas da música erudita tonal (Ex.8), como as volates em arco que saem do grave para o agudo e retornam ao grave (c.13-16, 20-21, 27, 28-29). A tessitura da Seção $A$ é mais ampla de todas, compreendendo duas oitavas e uma quinta justa (Dó ${ }_{3}$ a Sol ${ }_{5}$ ). Ainda dignas de nota, e ocorrendo no primeiro compasso da música, são a nota inicial Lá, que também será a última nota da música (superposta a um Sib!, como veremos à frente) e a articulação tipicamente hermetiana em staccato (nas $1^{\text {a }}, 3^{\text {a }}$ e $6^{\text {a }}$ notas, veja Ex.2 acima), já simulando a articulação do swing do jazz (em que as notas de apoio são um pouco mais longas) e, assim, antecipando a comunicação e homenagem ao jazzista e amigo Cannonball Adderley (saxofonista, mas também flautista, como Hermeto), falecido um ano antes da gravação do disco. Outra referência a esta comunicação que vai se estabelecer é o surgimento da primeira de uma série de cinco batidas de coração, que ocorre em [00:35]. As vozes superpostas ("oitavadas" ou não; em primeiro ou segundo planos), tornam-se mais presentes no meio da Seção $A$ e regridem ao final da mesma.

A Ponte ba (c.36-55; [02:37-03:07]; dur. 0'30"), que tem a notação Alegre de Hermeto na partitura original (a única indicação de andamento, por sinal), poderia ser chamada de "Contato inicial entre o mundo terreno e o mundo espiritual". É uma combinação de materiais temáticos das Seções $\boldsymbol{B}$ e $\boldsymbol{A}$ (Ex.9) e se divide em três pequenas partes. A primeira (c.36-44; [02:37-02:45]; dur. 0'08") é uma antecipação da Seção $B$ (que se inicia no c.56), tonalmente estável em Sol Eólio, com seu andamento rápido, sem swing, ritmo repetitivo e dançante, tessitura restrita e articulação em marcato. 0 crescendo finalizado com ataque brusco e respiração que havia ocorrido antes no c.17 da Seção $A$, volta a se repetir no c.44. A segunda parte (c.44-46; [02:45-02:55]; dur. 0'10") é um amálgama de características da Seção $A$ (a cadenza com volates ascendente e descendente) e da Seção $B$ (o andamento rápido e a articulação em marcato). A terceira parte, (c.47-55; [02:5503:07]; dur. 0'12") é uma recordação da Seção $B$, com seu andamento Lento e frases em legato cantabile de contorno melódico com saltos. 0 cromatismo ao final é um elemento articulador da forma que Hermeto lança mão nesta e nas outras seções de Cannon. As vozes superpostas retornam, continuam e se intensificam na Seção $B$.

A Seção B (c.56-138; [03:07:04:40]; dur. 1'33"), que tem o mesmo caráter Alegre (embora não marcado por Hermeto na partitura original) do início da Ponte ba, poderia ser chamada de "Comunhão entre o mundo terreno e o mundo espiritual". Ela epitomiza o encontro das culturas musicais

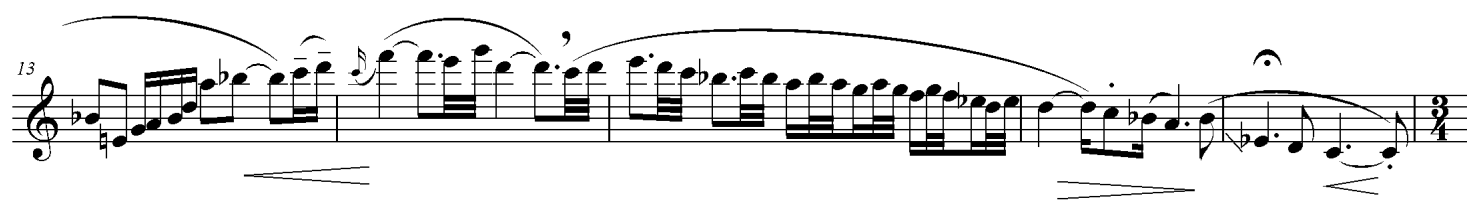

Ex.8 - Parte central da Seção A em Cannon de Hermeto Pascoal: escrita virtuosística erudita sugerindo cadenza.

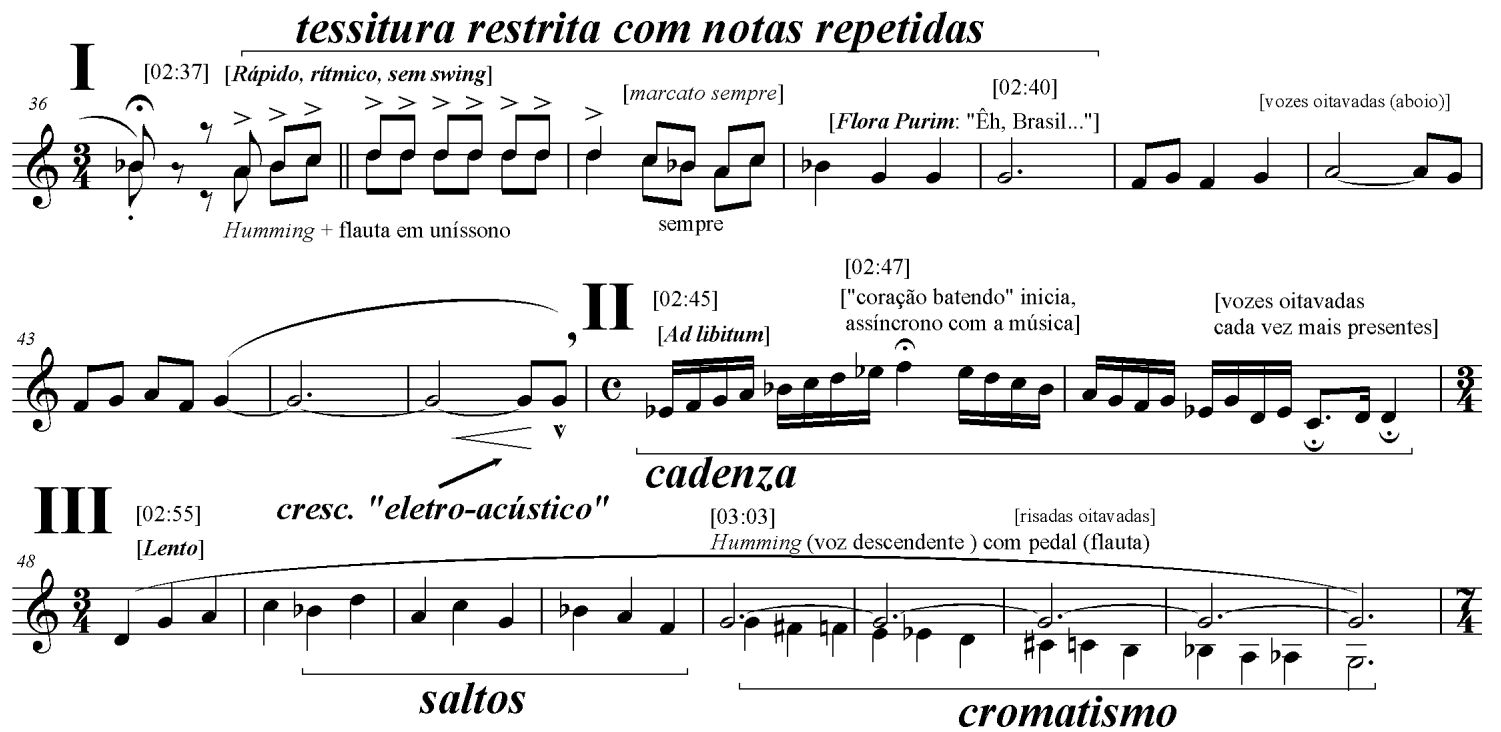

Ex.9 - Materiais temáticos nas três partes da Ponte ba em Cannon de Hermeto Pascoal, derivados das Seções $A$ e $B$. 
do nordeste (a embolada e o repente de Hermeto Pascoal) e dos Estados Unidos (o jazz de Cannonball Adderley), como mostra o trecho no Ex.10. É em andamento Dançante, rítmico, com um light swing, com articulação em marcato e métrica ternária na maior parte do tempo (apesar de se iniciar com um provocante $7 / 4+3 / 4)$. Harmônica e melodicamente, é caracterizada por uma grande estabilidade modal em Sol Eólio (c.56-94) e Sol Dórico (c.95-138), o que pode nos remeter tanto ao modalismo nordestino (SIQUEIRA, 1981) ou, no jazz, à herança modal dos históricos discos Milestones (1958) e Kind of blues (1959) de Miles Davis (KERNFELD, 1988, v.1, p.273; v.2, p.116-117). Esta estabilidade modal é enfatizada pelo humming da voz e flauta simultâneas de Hermeto em terças paralelas (c.91-94 e c.104-124). Além do swing, as blue notes Réb e Fá natural (c.107-108) são outro elemento jazzístico nesta seção em que a alma do norte-americano faz contato com os brasileiros. A tessitura é mais estreita, o que é típico nas danças populares: uma oitava e uma quinta justa ( Dó $_{3}$ a $\mathrm{Sol}_{4}$ ), com suas frases gravitando na maior parte do tempo em torno da tônica Sol ${ }_{3}$ e das dominantes Ré $_{3}$ e Ré ${ }_{4}$. A insistência na repetição de notas, associadas à imitação da voz do repentista nordestino no humming em terças paralelas com a voz, faz referência aos gêneros da embolada e do repente. As vozes superpostas e percussões se intensificam ao longo de toda a Seção $B$ e continuam na Seção $A^{\prime}$. Mas talvez o evento mais importante na Seção $B$ seja a sincronização temporária (como são os contatos entre médiuns e almas desencarnadas) entre a flauta de Hermeto e as "batidas de coração" de Cannonball (c.87-90, [03:47, 03:52]). Esta sincronização ocorre, proporcionalmente, a cerca de $2 / 3$ da duração da obra e coincide com a seção de maior atividade ritmica. Assim, percebe-se que a construção do clímax da obra segue a proporção áurea (veja Ex.5 acima).

A Seção $A^{\prime}$ (c.139-142; [04:40-04:57]; dur. 0'17"), que chamaríamos de "Volta ao mundo terreno", poderia ser entendida como uma coda, mas seu contraste com os materiais temáticos que a antecedem (Seção B) e o significativo retorno ao clima inicial da obra confirmam

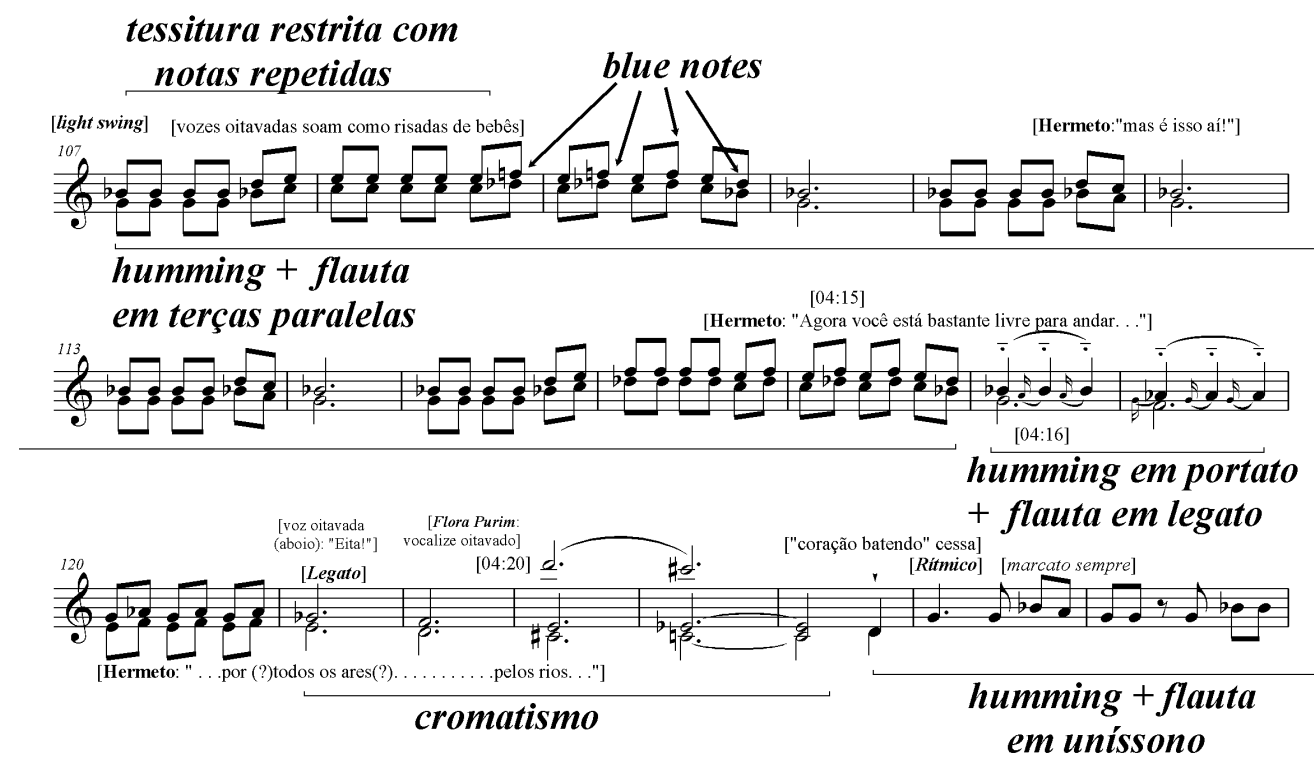

Ex.10 - Trecho da Seção B em Cannon de Hermeto Pascoal: encontro dos gêneros repente/embolada (ritmo dançante com notas repetidas, modalismo com tessitura estreita, imitação da voz do repentista nordestino no humming em terças com a flauta) e jazz (light swing, blue notes, modalismo pós-Miles Davis).

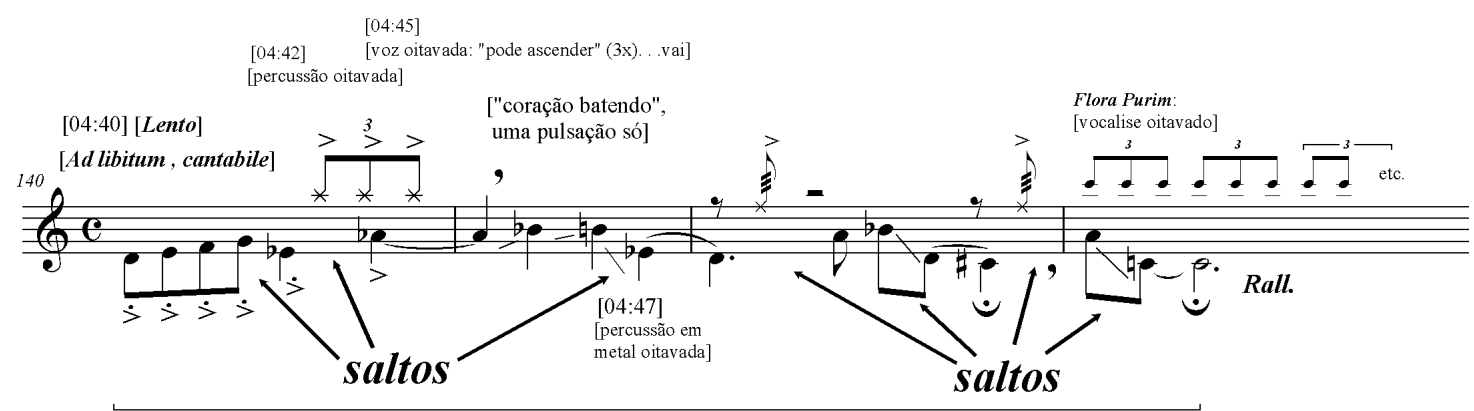

cromatismo e instabiliade modal

Ex.11 - Seção $A^{\prime}$ em Cannon de Hermeto Pascoal: recapitulação de materiais temáticos da Seção $A$. 
o fechamento em arco da forma (e da sessão espírita musical) de maneira sintética. Como ocorre na Seção $A$ inicial e em apenas quatro compassos, temos aí o mesmo andamento Lento ad libitum, a mesma instabilidade modal, a métrica quaternária, o cantabile das frases em legato e os contornos melódicos com saltos (Ex.11). As vozes superpostas e percussões continuam em toda a Seção $A^{\prime}$ e adentram na Codetta.

0 último compasso pode, pela sua natureza complexa e concentração de eventos e significados musicais, ser considerada uma Codetta (c.143; [04:57-05:13]; dur.00'16"). Observa-se aí a recapitulação não apenas da forma em arco de Cannon, mas também de eventos importantes que ocorreram ao longo da obra (Ex.12). Está presente a mesma nota Lá do início da música (humming + flauta) que, em seguida, sobe para o $\mathrm{Sib}_{3^{\prime}}$ lembrando o cromatismo que permeou todas as seções. Depois, o ambiente modalmente instável se instala com o movimento oblíquo entre a flauta (que permanece no $\mathrm{Si}_{3}$ ) e o humming da voz (que retorna para o Lá ${ }_{3}$ ). Este bicorde de segunda menor é sustentado como pedal por cerca de 10 segundos. Sobre este pedal, cresce a profusão de vozes "oitavadas". Também retornam as "batidas de coração". Este adensamento de texturas se dá por volta de $2 / 3$ da duração da Codetta, espelhando também a proporção áurea da obra como um todo, que ocorreu na Seção $B$ (veja Ex.5 acima). Após crescerem, as vozes manipuladas desaparecem com glissandi em fading. Depois, no exato final de Cannon, restam apenas umas poucas "batidas de coração", o mesmo coração (de Cannonball Adderley?) que Ruy Pereira colocou no centro da espiral de sua partitura artística (veja. Ex.4 acima).

Do ponto de vista da orquestração da flauta e da voz utilizada no humming na flauta, Cannon utiliza tessituras amplas, mais comuns na música erudita. A flauta vai desde sua nota mais grave, o Dó (c. 17, 26, 28, 46, 76, 100, 123, e142) até um Sol (c.14), ou seja, uma extensão de duas oitavas e uma quinta justa, o que é pouco comum na música popular. A voz cantada de Hermeto Pascoal, que na partitura publicada neste número de Per Musi (p.80-82), foi anotada na clave de Sol, mas soa sempre uma oitava abaixo, vai, em som real, desde o Sol (c.55) até o Sol ${ }_{3}$ (c.33), ou seja, uma extensão de duas oitavas, pouco comum tanto no canto da música popular quanto no humming erudito prescrito por ARTAUD (1995, p.119).

\section{4- Análise do continuum separação-fusão pa- radoxal de Cannon por Luiz Costa-Lima Neto} Como toda obra complexa, Cannon permite múltiplas leituras analíticas. Luiz Costa-Lima Neto, um dos mais importantes pesquisadores sobre a música de Hermeto Pascoal (veja seu artigo 0 cantor Hermeto Pascoal: a voz como instrumento neste número de Per Musi às p.4462; COSTA-LIMA NETO, 2010a), já havia se interessado em investigar Cannon pelos seus lados exótico, no qual identificou "sons de pássaros" - e místico, no qual identificou a "voz do próprio Hermeto, como se estivesse rezando" (COSTA-LIMA NETO, 2008, p.11). Consultado so-

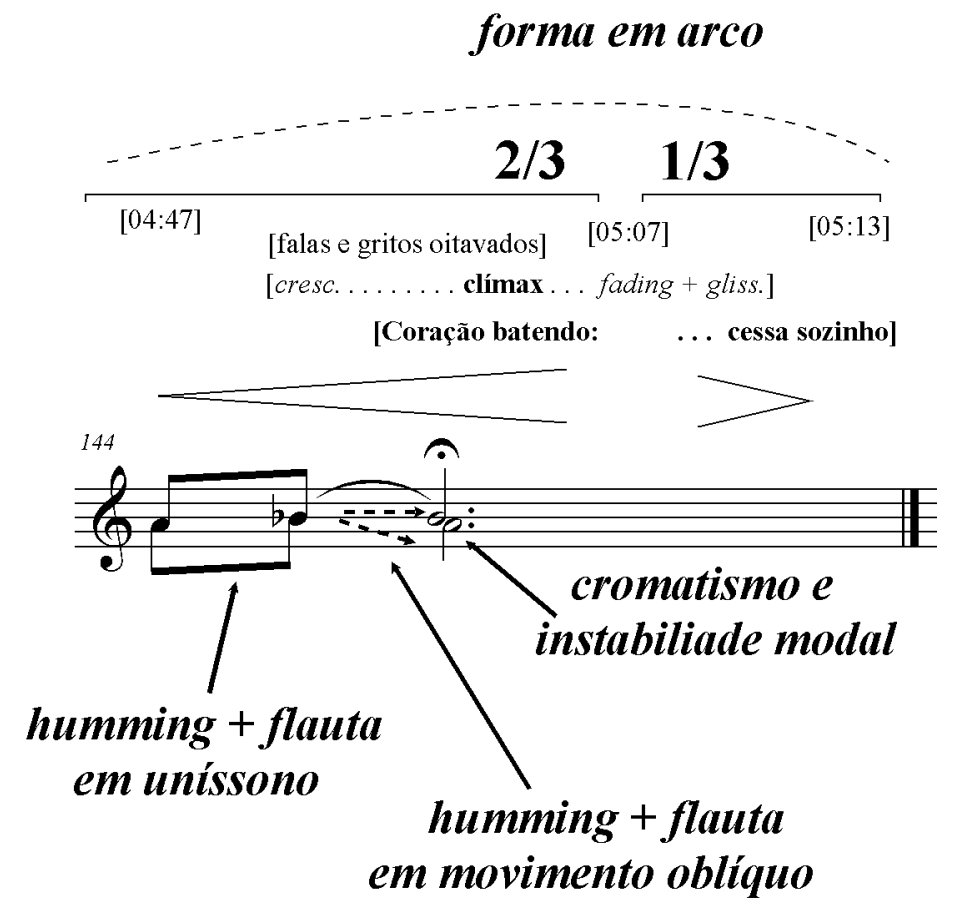

Ex.12 - Codetta em Cannon de Hermeto Pascoal: um único compasso com recapitulação da forma em arco da obra, de sua seção áurea e de materiais temáticos das Seções $A$ e $B$. 
bre nossa reconstrução e edição da partitura de Cannon, e sobre a pertinência de possiveis dados extra-musicais na sua gravação, Luiz Costa-Lima Neto nos propõe uma análise etnomusicológica com base no que chama de "continuum separação-fusão paradoxal" (COSTA-LIMA NETO, 2009), a qual apresentamos aqui em primeira mão. Ele desenvolveu esta ferramenta metodológica a partir da observação da fala de Hermeto Pascoal e sua percepção poiética do imaginário, da maneira como "sobrepõe pólos opostos. . . até fundi-los. . .", gerando um conjunto integrado de quatro fases inter-relacionadas, que pode ser constatado ". . . tanto nas peças improvisadas como nas composições escritas."

Para ele, Cannon pode ser compreendida como uma forma binária $A B$, precedida de introdução e finalizada por uma coda. Do ponto de vista ritualístico, o ouvinte passaria por uma preparação da sessão espírita (introdução; c.16), que levaria à busca e estabelecimento de contato com o espírito desencarnado $(A ; c .7-55)$, que levaria ao transe da incorporação ( $B$; c.56-138) e que, finalmente, levaria a um retorno da consciência (coda; c.139-143). Na primeira fase de Cannon, que chama de Separação, COSTALIMA NETO (2009) identifica a abertura da sessão espírita (c.1-6; [00:00-00:35]), com uma "prece sem palavras", realizada apenas pela flauta solo. Na segunda fase, que chama de Melodia ou embolada de opostos [numa alusão ao gênero nordestino], o contexto ritualístico sugere uma invocação espiritual (c.7-55; [00:35-03:07]) coletiva do "doutrinador" (Hermeto Pascoal) com a ajuda dos outros "médiuns" (demais músicos presentes na gravação, citados anteriormente) que criam uma "Atmosfera lúdica. . . positiva. . . adequada ritualmente à sessão espírita musical", em que "os opostos estão se aproximando...". A terceira fase, que chama de Harmonia de opostos, (c.56138; [03:07-04:40]) equivaleria ritualmente ao clímax e transe do contato e incorporação espiritual: em meio à multitude de efeitos instrumentais e vocais, convivem 0 sonhar e o estar acordado, a consciência e a inconsciência, os espíritos encarnados e os desencarnados; as blue notes indicariam ". . que o espírito do jazzista Cannonball Adderley 'baixou'..." e que se liberta ("Agora você está bastante livre para andar em todos os ares, em todos os mundos, now you're free!..."). Na quarta fase, que chama de Fusão paradoxal, (c.139-143; [04:40-05:13]) equivaleria ao fechamento da sessão espírita, há um retorno à atmosfera inicial, mas diferente pelas reminiscências do transe atingido na terceira fase:

\footnotetext{
". . .movimento de relaxamento (parcial) e, simultaneamente, retenção do tensionamento. . ... . o o estado de vigília é parcialmente restabelecido, mas a consciência e a inconsciência não estão separadas como na fase inicial, pois foram unidas e englobadas por uma instância supraconsciente, espiritual, o 'Outro-eu transcendente' (conceito cunhado pelo etnomusicólogo inglês John Blacking)."
}

\section{5- Considerações finais}

Cannon é uma obra pioneira na música popular brasileira, até onde sabemos, por ser a primeira utilizar a manipulação e utilização de sons pré-gravados em estúdio junto a um solo instrumental. Mais do que isso, é um retrato da genialidade e dom de Hermeto Pascoal para transformar qualquer som em música, como falas e ruídos, mesmo aqueles gerados no cotidiano, às vezes sem nenhuma relação com o programa ou materiais temáticos da obra.

Podemos caracterizar Cannon como uma música funcional, cujo objetivo foi prover uma sessão espírita para Hermeto Pascoal e seus companheiros brasileiros nos Estados Unidos se comunicarem com o recém falecido músico norte-americano Cannonball durante a gravação do disco Slaves mass em 1977. Por outro lado, Cannon apresenta uma construção complexa, mais comum na música erudita, cujas proporções apresentam uma estrutura em arco cujo clímax e principal sincronicidade (quando os duplos Hermeto/flauta e Cannonball/"batidas de coração" entram em fase) coincidem com a seção áurea da obra. Mais do que isso, a complexidade de Cannon é aparente em níveis mais locais em toda a obra, com a exploração de melodias de grande tessitura, saltos e volates, a utilização de uma linguagem modal instável que beira o atonalismo e a bi-modadidade, de técnicas instrumentais avançadas (harmônicos, glissandi, timbres ruidosos) e expandidas (multifônicos de oitava e terça, vários tipos de humming).

0 gradual acréscimo dos sons pré-gravados, manipulados ou não, sobre a improvisação na flauta, é de tal ordem organizado que estimula o ouvinte, ao longo da forma, à sensação de presenciarem um ritual espírita completo, em que o doutrinador e demais médiuns primeiro rezam, depois entram em transe, no clímax encontram com a alma que procuram (Cannonball Adderley), a tranquilizam e, finalmente, se despedem para retornarem ao mundo terreno. Do ponto de vista da instrumentação, podemos ainda associar os sons não manipulados (flauta, hummings, vozes declamando em português e inglês) ao mundo terreno e os sons manipulados (falas, risadas, gritos, vocalizes e percussão "oitavados" pelo dobramento da velocidade de reprodução da fita gravada) ao mundo espiritual.

Cannon é bem ilustrativa da linguagem eclética e híbrida de Hermeto Pascoal. Podemos observar, nesta obra, sua abertura para uma música sem fronteiras entre 0 popular e o erudito, sem fronteiras entre os estilos tipicamente nacionais (embolada, repente) e estrangeiros (jazz, a cadenza do concerto clássico, música concreta). A sofisticação da escrita composicional e idiomática de Hermeto Pascoal para a flauta, juntamente com sua criativa integração dos recursos expressivos eletro-acústicos ao seu conteúdo programático, criam um grande sentido de unidade em Cannon que, por si só, deveria resgatá-la do ostracismo para fazer parte, ao lado de outras obras primas afins do repertório solístico da flauta - como Syrinx (1913) para flauta solo de C. Debussy, Density 21,5 (1936) para flauta solo de E. Varèse e Synchronisms N.1 (1962) para flauta solo e tape com sons sintetizados de Mario Davidovsky -, seja esse repertório erudito, popular ou, como nos ensina a natureza universal de Cannon e Hermeto Pascoal, popular-erudito. 


\section{Referências de texto}

ARTAUD, Pierre-Yves. Flûtes au présent: traité dês techniques contemporaines sur lês flûtes traversières à lúsage des compositeurs et des flûtistes. Paris: Gerard Billaudot, 1995.

BARBOSA, Marco Antonio. 0 forró de Hermeto Paschoal. Cybernotas. Artigo publicado em 6 de julho, 2001. In: www.cliquemusic.uol. com.br (Acesso em 7 de janeiro de 2009).

BARROSO, Fabiano et al. Nunca falei não, eu falo agora, agora eu falo: Hermeto Pascoal. Graffiti 76\% Quadrinhos. 2009. In: www.graffiti76.com/entrevistas.html (Acesso em 6 de fevereiro, 2009).

BORÉM, Fausto; ARAÚJO, Fabiano. Hermeto Pascoal: experiência de vida e a formação de sua linguagem harmônica. Per Musi, n.22. Belo Horizonte: UFMG, 2010. p.22-43.

CAMPOS, Lucia Pompeu de Freitas Campos. Tudo isso junto de uma vez só: o choro, o forró e as bandas de pífano na música de Hermeto Pascoal. Belo Horizonte: UFMG 2006 (Dissertação de Mestrado).

COSTA-LIMA NETO, Luiz. A música experimental de Hermeto Pascoal e Grupo (1981-1993): concepção e linguagem. Rio de Janeiro: Unirio, 1999. (Dissertação de Mestrado). http://teses.musicodobrasil.com.br/a-musica-experimental-dehermeto-pascoal-e-grupo.pdf. [Disponível em inglês como "The experimental music of Hermeto Pascoal and Group (1981-1993): conception and language": http://teses.musicodobrasil.com.br/luiz-costa-lima-the-experimental-music-of-hermeto-pascoal-and-group.pdf in Músicos do Brasil: Uma Enciclopédia Instrumental .

Análise de Cannon. E-mail de Luiz Costa-Lima Neto a Fausto Borém (24 Fevereiro de 2009).

0 Calendário do Som e a estética sociomusical inclusiva de Hermeto Pascoal: emboladas, polifonias e fusões paradoxais. Revista USP. n.82. São Paulo: USP, 2010a.

0 cantor Hermeto Pascoal: a voz como instrumento. Per Musi, n.22, p.44-62. Belo Horizonte: UFMG, 2010 b.

Da casa de Tia Ciata à casa da Família Hermeto Pascoal no bairro do Jabour: tradição e pós-modernidade na vida e na música de um compositor popular experimental no Brasil. Música \& Cultura, revista on-line de etnomusicologia. n.3. Salvador: UFBA, 2008. [(www.musicaecultura.ufba.br, acesso em 9 de janeiro, 2009). Disponível em inglês como "From the house of Tia Ciata to the house of the Hermeto Pascoal Family in Jabour: tradition and post-modernity in the life and music of a popular experimental composer in Brazil": http://ensaios.musicodobrasil.com.br/luizcostalimaneto-traditionandpostmodernity-hermeto-pascoal.pdf in Músicos do Brasil: Uma Enciclopédia Instrumental . http:// www.musicosdobrasil.com.br/inicio.jsf , 2009.]

EMMERSON, Simon; SMALLEY, Denis. Electro-acoustic music. In: The New Grove dictionary of music and musicians. 2 ed. Stanley Sadie, editor.jJohn Tyrell, diretor executivo. Londres: Macmillan, 2001.

GILMAN, Bruce. Sorcerer's apprentice. sem data. In: Brazzil Magazine. 2009 (www.brazzil.com/musdec96.htm, acesso em 10 de janeiro, 2009).

GIRON, Luis Antônio. Mário Reis: o fino do samba. Coleção Todos os Cantos. São Paulo: Editora 34, 2001.

GONTIJO, Murilo. Minha religião é a música. Boletim informativo da UFMG. n.1285, ano 26, 19 de julho de 2000. p.5. In: www.ufmg.br/boletim/bol1285 (Acesso em 7 de janeiro, 2009). http://www.musicosdobrasil.com.br/inicio.jsf , 2009.]

KRICH, John. Why is this country dancing?: a one-man samba to the beat of Brazil. New York: Simon \& Schuster, 1993.

KERNFELD, Barry (ed). The New Grove dictionary of jazz. 2 vls. Londres: Macmillan, 1988.

LEECH-WILKINSON, Daniel. Portamento e significado musical. Per Musi, n.15. Belo Horizonte: UFMG, 2007. p.7-25.

MILLARCH, Aramis. Abertura (Opus 5). Tablóide digital. In: www.millarch.org. 1979 (Acesso em 21 de janeiro de 2009; publicado anteriormente no Estado do Paraná, 15 de abril de 1979, p.1).

0 Som da gente em terra de Marlboro. Tablóide digital. In: www.millarch.org. 1989 (Acesso em 21 de janeiro de 2009; publicado anteriormente no Estado do Paraná, Caderno Almanaque, 14 de março de 1989, p.3).

Som contemporâneo. Tablóide digital. In: www.millarch.org. 1977 (Acesso em 21 de janeiro de 2009; publicado anteriormente no Estado do Paraná, Jornal da Música, 3 de julho de 1977, p.29).

PASCOAL, Hermeto. Biografia. In: www.hermetopascoal.com.br. 2009a (Acesso em 9 de janeiro, 2009).

Discografia. In: www.hermetopascoal.com.br. 2009b (Acesso em 9 de janeiro, 2009).

POLITOSKE, Daniel T. Music. 5a ed. Englewood Cliffs, New Jersey: Prentice Hall, 1992.

PRADINES, César. Música brasileña en pareja. La Nacion. Espetáculos. 13 de maio, 2006. In: www.lanacion.com.ar. (Acesso em 10 de janeiro, 2009).

PURIM, Flora. Texto de apresentação do LP Slaves mass. In: Slaves Mass (capa interna do LP). Hermeto pascoal (voz, piano, Fender Rhodes, violão, flauta doce e transversal, saxofone e clavineta), Flora Purim (voz), Airto Moreira (percussão, voz e porcos), Raul de Souza (trombone e voz), David Amaro (violão, guitarra e viola de doze cordas), Ron Carter (contrabaixo acústico), Alphonso Johnson (contrabaixo elétrico), Chester Thompson (percussão), Hugo Fattoruso (voz), Laudir de Oliveira (voz). WEA/Warner: BS2980, 1977. (LP)

RAHSAAN ROLAND KIRK. In: Wikipedia. www.alfanet.hu/kirk. (Acesso em 1 de fevereiro, 2010).

RODRIGUES, Otávio. Hermeto. Vida simples. Dezembro, 2003. In: www.vidasimples.abril.com.br (Acesso em 12 de janeiro, 2009).

SANTOS NETO, Jovino. Re: Cannon do Slaves Mass. (e-mail de Jovino Santos Neto a Fausto Borém em 16 de janeiro de 2009). 
SIQUEIRA, José de Lima. Sistema modal na música folclórica do Brasil. João Pessoa: Secretaria de Educação e Cultura diretoria geral de cultura, 1981.

VILLAÇA, Edmiriam Módolo. O Menino Sinhô, vida e música de Hermeto Pascoal para crianças. llustrações de Rosinha Campos. Carta de Zélia Gaia. São Paulo: Ática, 2007.

ZWARG, Itiberê. A música universal. In: www.itibereorquestrafamilia.com.br. 2009a (Acesso em 20 de janeiro, 2009).

\section{Referências de partitura}

PASCOAL, Hermeto; BORÉM, Fausto. Cannon (dedicada a Cannonball Adderley) para flauta, humming na flauta e sons pré-gravados. Partitura transcrita e editada por Fausto Borém a partir da gravação do compositor no disco Slave Mass (1977). Per Musi, n.22. Belo Horizonte: UFMG, 2010. p.80-82.

PASCOAL, Hermeto; PEREIRA, Ruy. Cannon (Partitura transcrita por Hermeto Pascoal e desenhada por Ruy Pereira). In: Slaves Mass (capa interna do LP). Hermeto pascoal (voz, piano, Fender Rhodes, violão, flauta doce e transversal, saxofone e clavineta), Flora Purim (voz), Airto Moreira (percussão, voz e porcos), Raul de Souza (trombone e voz), David Amaro (violão, guitarra e viola de doze cordas), Ron Carter (contrabaixo acústico), Alphonso Johnson (contrabaixo elétrico), Chester Thompson (percussão), Hugo Fattoruso (voz), Laudir de Oliveira (voz). WEA/Warner: BS2980, 1977. (LP)

\section{Referências de gravação}

PASCOAL, Hermeto. Cannon. In: Slaves Mass. Hermeto pascoal (flauta e voz) com participações vocais de Flora Purim, Airto Moreira, Hugo Fattoruso, Raul de Souza e Laudir de Oliveira. WEA/Warner: BS2980, 1977. (LP)

RAHSAAN, Roland Kirk. I talk with the spirits. Limelight, Nola's Penthouse Sound, 1964 (LP re-masterizado como CD de áudio; fragmento sonoro disponivel em www.amazon.com/Talk-Spirits-Rahsaan-Roland-Kirk)

\section{Notas}

1 Segundo VILLAÇA (2007, p.59) e PRADINES (2006), Hermeto Pascoal teria escrito mais de 4.000 músicas até 2007.

20 nome "Cannonball" é uma corruptela do apelido "cannibal", uma referência ao grande apetite do músico Julian Adderley na infância (KERNFELD, 1988, p.5).

3 Hermeto Pascoal é um dos mais reconhecidos multi-instrumentistas da história da música popular. É mais conhecido como virtuoso da sanfona, fole de oito baixos, piano, flautas e saxofones. Entretanto, tem demonstrado sua versatilidade e virtuosismo em muitos outros instrumentos convencionais, entre eles teclados eletrônicos diversos, harmônio, cravo, órgão, escaleta, flauta de bambu, bombardino, fluguel, trumpete, violão, cavaquinho, viola caipira, bandola, craviola, clavinete, bateria, surdo caixa, surdo, zabumba, pandeiro, pratos, triângulo - e em instrumentos exóticos, objetos e animais, como bocal de tuba, sapho, garrafas, berrante, assovio, buzinas, apitos, brinquedos, chaleira, máquina de costura, baldes, bacias, panelas, garfos, facas, balas, ruídos e gritos da voz, mangueira com voz, porta do estúdio, iefone, porcos, gansos, perus, galinhas, patos e coelhos (PASCOAL, 2009a, 2009b).

4 Seção áurea é a divisão de uma linha em duas partes de maneira que a proporção do segmento menor para o segmento maior é igual à proporção do segmento maior para a somatória dos dois segmentos. Os segmentos equivalem a 0.618 e 0.382 do todo, o que é aproximadamente $2 / 3$ e $1 / 3$. Esta proporção é também encontrada com bastante aproximação na Série Fibonacci (1, 1, 2, 3, 5, 8, 13 etc.). Para outros exemplos do uso da seção áurea em música veja o livro Bela Bartók: An Analysis of His Music (Lendvai, 1971) e o artigo Bartók, Lendvai and the Principles of Proportional Analysis (Howat, 1983).

5 Para uma discussão aprofundada sobre a substituição histórica do portamento pelo vibrato na música erudita veja LEECH-WILKINSON em Per Musi, n.15 (2007, p.7-25).

6 Há muitas discrepâncias entre a transcrição de Cannon por Hermeto publicada na capa interna de Slaves mass (1977) e a gravação da música no mesmo disco. Algumas das diferenças relevantes são: dúvidas na notação de notas (Lá3 ou Dó4 no c.13; acidentes nos Lás do c.27; Si natural, Fá\# e Lá natural no c.30; Fás no c.85; falta um bequadro no c.111; seria um bemol no Si do c.124?), notação simplificada de vozes, efeitos e dinâmicas (nenhuma voz realizada em humming é anotada; efeitos como glissandi e multifônicos não são anotados; observa-se apenas um crescendo no c.6), diferenças na notação de notas, ritmos e métrica (mínima no c.32; colcheias no c.83; quaternário nos c.119 ou 120 ; fusas do c.15 anotadas com quiálteras; fusas dos c.20-21 anotadas como semicolcheias; sextinas do c.29 simplificadas como colcheias; omissão de várias notas no c.30; omissão de um grande trecho lento - c.47-55 - em que há um humming cromático descendente com o pedal da flauta em Sol; o c.69 é anotado como um compasso quaternário, quando o correto é um ternário; semicolcheias do c.133 simplificadas como uma colcheia), inconsistência na notação da forma (repetição no c.88). 
Fausto Borém é Professor Titular da Escola de Música da Universidade Federal de Minas Gerais (UFMG), onde criou o Mestrado em Música e a Revista Per Musi. É pesquisador do CNPq desde 1994 e seus resultados de pesquisa incluem um livro, três capítulos de livro, dezenas de artigos sobre práticas de performance e suas interfaces (composição, análise, musicologia, etnomusicologia e educação musical) em periódicos nacionais e internacionais, dezenas de edições de partituras e apresentação de recitais nos principais eventos nacionais e internacionais do contrabaixo. Recebeu diversos prêmios no Brasil e no exterior como solista, teórico, compositor e professor. Acompanhou músicos eruditos como Yo-Yo Ma, Midori, Menahen Pressler, Yoel Levi, Fábio Mechetti, Luiz Otávio Santos, Arnaldo Cohen, Antônio Menezes e músicos populares como Hermeto Pascoal, Egberto Gismonti, Henry Mancini, Bill Mays, Kristin Korb, Grupo UAKTI, Toninho Horta, Juarez Moreira, Tavinho Moura, Roberto Corrêa e Túlio Mourão. Suas gravações incluem o CD Brazilian Music for the Double Bass, o CD e DVD 0 Aleph de Fabiano Araújo Costa, os CDs da Orquestra Barroca do Festival Internacional de Juiz de Fora de 2005 a 2009 (com Luiz Otávio Santos), a Suite for Flute and Jazz Piano de Claude Bolling (com Maurício Freire, Tânia Mara e Eduardo Campos) e No Sertão (com o violista Roberto Corrêa) e Cidades Invisíveis (com o saxofonista Daniel d'Olivier).

Mauricio Freire Garcia é Professor Adjunto da UFMG, onde já atuou como Diretor da Escola de Música e Diretor Adjunto de Relações Internacionais. Graduado pela mesma instituição em 1987, é o único flautista a receber o título de Doutorado, com honras, no New England Conservatory, EUA. Desde 2003, tem atuado como $1^{\circ}$. Flautista Solista convidado da OSESP. Trabalhou com importantes compositores como Thea Musgrave, Ezra Sims, H. J. Koellreuter e Eduardo Bértola atuando no Boston MusicaViva, um dos principais grupos de música contemporânea dos EUA, e no Grupo de Música Contemporânea da UFMG. Já se apresentou nas principais salas do país além dos EUA, Europa e América do Sul. Em Boston se destacou como solista junto à Boston Chamber Music Society, o New England Conservatory Bach Ensemble e Contemporary Ensemble. Em 2005, apresentou-se ao lado do pianista Nelson Freire no Festival Piano aux Jacobins em Toulouse, França. Mantém, desde 1998, duo com o pianista Miguel Rosselini, com quem realizou uma série de recitais na Alemanha em 2008 e gravou um CD, lançado em 2009. Suas gravações incluem a Suíte em Si menor de Bach, Suite for Flute and Jazz Piano de Claude Bolling, Choros de Abel Ferreira e diversos CDs com a OSESP. 